\title{
Analysis of Credit Access, U.S. Agricultural Productivity, and Residual Returns to Resources
}

\author{
Darlington Sabasi ${ }^{1 *}\left(\mathbb{D}\right.$, C. Richard Shumway ${ }^{2}$ and Lyudmyla Kompaniyets ${ }^{3}$ \\ ${ }^{1}$ Portfolio Modeling, ACES Power Marketing in Carmel, IN, USA, ${ }^{2}$ Regents Professor Emeritus in the School of Economic \\ Sciences, Washington State University, Pullman, WA, USA and ${ }^{3}$ Division of Nutrition, Physical Activity, and Obesity, \\ National Center for Chronic Disease Prevention and Health Promotion, Center for Disease Control in Atlanta, GA, USA \\ *Corresponding author. Email: sabasidr@gmail.com
}

\begin{abstract}
We examine the relationship credit access has had with the U.S. agricultural productivity and residual returns to resources. Our theoretical analysis suggests that limited credit access can be sufficient to prevent a representative farmer from maximizing both short- and long-run profits. Empirical results show that increased credit access is positively associated with both productivity and residual returns to resources. Our findings imply that one way to stimulate the U.S. agricultural productivity growth is to increase credit access. They also provide strong empirical support for the productivity-stimulating value of programs such as the Farm Service Agency's Farm Loan Program.
\end{abstract}

Keywords: credit access; productivity; profit; U.S. agriculture

JEL Classifications: G21; G32; D24

\section{Introduction}

Following its downturn after the 1980s farm financial crisis, real U.S. agricultural debt has been rising since the early 1990s (Figure 1). Trends also show an increase in debt concentration among fewer farms (Harris et al., 2009). In 2011, large-scale and midsize family and nonfamily farms constituted only $10 \%$ of U.S. farms, but produced $75 \%$ of the value of the U.S. agricultural output and held $95 \%$ of total U.S. farm debt (Hoppe, 2014).

Credit is supplied to the U.S. farmers from a variety of sources, including the Farm Credit System (FCS), large commercial banks, the Farm Service Agency, life insurance companies, Farmer Mac, input suppliers, and equipment dealers (USDA-ERS, 2021). The amount of credit supplied to the U.S. farm sector is dependent both on governmental regulation of the financial sector and the financial health of the farm sector. For example, Moss and Suh (2020) found that the Ability-to-Repay rule embedded in the 2010 Dodd-Frank Act increased compliance costs, which in turn negatively affected the supply of agricultural credit. Key et al. (2019) noted that the decline in farm sector income and deceleration in farm real estate appreciation is partially responsible for recent concerns about the financial health of the U.S. farm sector.

Agricultural firms rely heavily on debt capital in combination with their own equity capital for financing and planning operations (Cadot, 2013; Gardner and Rausser, 2001; Mugera and Nyambane, 2015). The demand for credit by farms is affected by internal funds, structural shifts in production methods that are enhanced on larger farms, the long production period, and the inherently risky nature of agricultural production. 


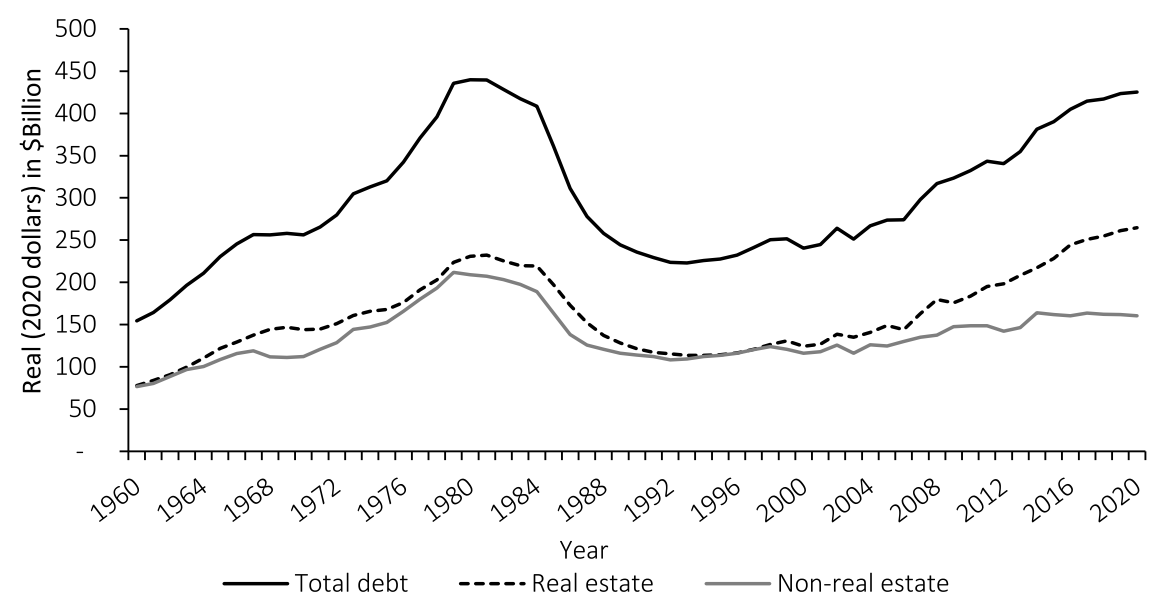

Figure 1. Farm sector debt.

Data Source: USDA/ERS Farm Balance Sheet (2020), 2019 and 2020 values are forecasted.

Since firms often use internal funds before turning to debt, one reason for which is to eliminate transaction costs (MacKie-Mason, 1990) and another to benefit from asymmetric information (Fazzari et al., 1988; Myers and Majluf 1984), the growing farm loan volume and its concentration suggest that internally generated funds (equity) may be insufficient to achieve desired production levels on some farms. The structural shift of agriculture towards advanced technologies (Barry and Robison, 2001), especially those embodied in new capital, presents a major financial challenge for farmers who invest in such technologies while trying to meet other financial needs of the farm. Additionally, the large-scale and midsize family and nonfamily farms producing most of the U.S. agricultural output use more capital-intensive production methods with labor substituted by advanced technologies. These highly productive and mechanized farms employ a tiny share of the U.S. workforce and use millions of tractors in place of the horses and mules of earlier days (Dimitri et al., 2005). The long lag between the beginning of the production period (generally characterized by increased cash outflow) and the marketing period (when farmers begin receiving cash inflow) induces farmers to seek external financing for operating loans. The risky nature of agricultural production makes external financing critical when random shocks (such as weather or commodity price volatility) leave farmers without sufficient operating capital.

Thus, the dynamic nature of the U.S. financial markets, the recent financial challenges facing the U.S. agriculture, and the varied finance needs of this highly capital-intensive sector warrant revisiting the role of credit in the U.S. agriculture. The critical question is whether the aggregate supply of external credit has been insufficient for the farm sector to maximize either productivity or returns to resources.

In this article, we examine the relationship credit access has had with the U.S. agricultural productivity and residual (net) returns to resources (unpaid labor and land). We hypothesize that increased credit access is positively correlated with both residual returns to resources and productivity in this sector. Positive correlation of credit access and residual returns to resources stems from the profit-maximizing behavior of farms. Positive correlation of credit access and productivity could emanate from its potential impact on technical change, technical efficiency, and scale and mix efficiency, the drivers of the U.S. agricultural productivity growth (O'Donnell, 2012). Credit may contribute to technical change (shifting the production frontier upward) by enabling farmers to adopt more advanced technologies. Credit may contribute even more to technical efficiency (getting the largest possible output from a given set of inputs with a given technology) by enabling farmers to improve managerial performance, which may include being more timely in critical operations such as repairing and maintaining equipment. It may contribute to scale and 
mix efficiency by facilitating the expansion of inputs as well as adjustments in the input and output mix, which may include hiring specialized labor to carry out particular tasks. ${ }^{1}$

Our hypothesis of a positive correlation between credit access and productivity presumes that the positive impacts of additional credit on productivity more than compensate for its negative impact of allowing less efficient firms to persist at the expense of new and potentially more efficient firms entering the market. We base our hypothesis on the competitive nature of the U.S. agriculture with its minimal barriers to entry and exit. ${ }^{2}$

Assuming that farmers exhibit profit-maximizing behavior in competitive markets with constant prices, the long-run profit-maximizing input and output levels (accounting for the shifting production frontier) are simultaneously productivity-maximizing when market prices are used as weights to create aggregate output and input indices. ${ }^{3}$ In the short run, the effect of credit access may impact productivity differently than it impacts residual returns to resources. If supported, our hypothesis implies that lack of agricultural credit is highly constraining to optimal production patterns, and that both short-run and long-run profit are credit constrained.

For developing countries, limited access to credit is a major challenge for farmers that have significant adverse impacts on farm investment (Carter and Olinto, 2003) and farm profit (Foltz, 2004). Its improvement has a positive impact on productivity and value of agricultural output (e.g., Gatti and Love 2008; Guirkinger and Boucher, 2008).

Although often considered mainly a developing country issue, prior studies have concluded that the U.S. farms also face binding and non-negligible credit constraints (e.g., Briggeman, et al., 2009b; Chaddad et al., 2005; Hartarska and Nadolnyak, 2012; Mishra et al., 2008). Limited credit has been found to adversely impact the U.S. farm income and output (Briggeman, et al., 2009b; Nadolnyak et al., 2017), rural economic growth (Hartarska, et al., 2015), Tennessee small farms' financial performance (Khanal and Omobitan, 2020), amount of farm inputs used (Kumar et al., 2013), Midwest grain yields (Butler and Cornaggia, 2011), and farm efficiency (Chavas and Aliber, 1993). Mugera and Nyambane (2015) observed that the technical efficiency of broadacre farms (large-scale agricultural or pastoral enterprises that produce grains, oilseeds, or other crops or graze livestock for meat or wool) in Western Australia was positively related to short-term debt.

Our study is closely related to Butler and Cornaggia (2011) who pose a similar question and focus on Midwestern states for the period 2000-2006. We differ from their study in three ways. First, they focus only on Midwestern states over the period 2000-2006, while we investigate the impact of credit access in all 48 contiguous U.S. states over a much longer period, 1966-2003. Second, they use crop yield (i.e., output per unit of land) as a measure of productivity. This is a partial productivity measure. Ball et al. (2013) note that growth in land productivity depends on changes in the use of other inputs. Hence, crop yield is less informative than total factor productivity (TFP) (measured as the ratio of aggregate outputs to aggregate inputs) as used in this article. Third, whereas Butler and Cornaggia (2011) focus on the indirect measure of credit access (bank deposits), we use one direct and comprehensive credit access measure (real total debt per farm) and one direct credit access measure for production (commercial banks' real production loans per farm). As part of our robustness checks, we use two additional direct measures for loans supplied by commercial banks (real agricultural loans per bank office and real agricultural loans per farm) as well as indirect credit access measures representing the financial health of both lenders and farmers.

\footnotetext{
${ }^{1}$ Scale and mix efficiency is movement around the production frontier to capture economies of scale in addition to movement from one production frontier for which the input and/or output mix is fixed to another production frontier that captures economies of scope by changing the mix (O’Donnell, 2012).

${ }^{2}$ While there are no institutional barriers to entry and exit, the capital-intensive nature of agriculture could be regarded as a barrier. Further, the fact that the number of farms is declining is regarded by some as indirect evidence of barriers to entry.

${ }^{3}$ The output and input data we use from the USDA Economic Research Service are computed using effective market prices that include government payments and other relevant producer receipts and costs to compute revenue shares to aggregate outputs and cost shares to aggregate inputs.
} 
The data period is admittedly historical rather than current. It is necessitated by the lack of recent state-level data. Although dated, this period includes two decades of much more rapid rise in farm debt than has occurred recently as well as a decade of rapid decline. Our data period ends with a decade of rising farm debt, slower than the rise since 2003, but the rise since 2003 has been much slower than the rise between 1960 and 1980. Thus, understanding the relationship of TFP ${ }^{4}$ and residual returns to changes in farm debt during our data period could inform understanding of the current environment. Many of the important factors noted earlier that have affected the supply of agricultural credit in recent years also applied during portions of our historical data period.

Our results show that improved credit access is positively associated with both agricultural productivity and residual returns to resources. These results remain largely consistent and robust using both direct and indirect credit access measures and after controlling for various uncertainties in the model structure. They also consistently show that credit access is more restrictive to maximizing TFP for smaller farms than for larger ones and that the mean estimated impact of credit access is nearly two-thirds as great as the impact of public research investments and spill-ins over the range of our data. Similar to research evidence for developing countries, these findings imply that one way to stimulate the U.S. agricultural productivity growth is to increase credit access. This will, in turn, enable technology and advanced input adoption, gains in efficiency, and input and output mix adjustment in response to climate change, weather uncertainty, and/or input and output price changes.

\section{Theoretical framework}

Because of the large number of firms and generally homogeneous products, we assume that agricultural producers seek to maximize profit subject to an acceptable amount of risk and that they operate in perfectly competitive input and output markets. ${ }^{5}$ We also treat interest rates to farmers as exogenous due to the small percent of agricultural loans compared to total loans (between 2.0 and $5.6 \%$ during our study period). ${ }^{6}$

If credit access is sufficiently limiting that it becomes a binding constraint that prevents the farm from reaching its optimal output and input levels, the farmer's short-run profit is reduced. Productivity (or long-run profit) may also be reduced, but the effect of limited credit access on productivity is ambiguous. If limited credit access is binding on maximum TFP such that it moves production into the region where the marginal product $(\mathrm{MP})>$ average product $(\mathrm{AP})$, relaxing credit access constraints increases both productivity and short-run farm profit. ${ }^{7}$ If limited credit access is binding in the short-run profit maximization problem but not in the productivity maximization problem, increasing credit access only increases short-run farm profit but may not increase farm productivity. The economically feasible region of production in the short-run for competitive firms is the region of locally-decreasing returns to scale (as implied by $\mathrm{MP}<\mathrm{AP}$ ). In this region, productivity falls if there is no shift in the production frontier and short-run profit rises as efficient competitive firms move from the potentially TFP-maximizing point to the short-run profit-maximizing point.

Since credit access is a function of both the farmer's and lender's financial health, we must also consider the lender's motivation to provide loans to farmers. Recognizing that there are several types of lenders (including the FCS and commercial banks), agricultural loans are a small portion of total loans, and money is fungible and will move to where there is a greater return, we also treat

${ }^{4} \mathrm{TFP}$ is calculated as a ratio of aggregate output quantities (Y) to aggregate input quantities (X). TFP for state $i$ in time period $t$ is calculated as $T F P_{i t}=Y_{i t} / X_{i t}$.

${ }^{5}$ Throughout this paper, our references to profit maximization implicitly assume it is subject to an acceptable risk threshold.

${ }^{6}$ Percent of agricultural loans (farmland loans + agricultural production loans) was calculated using data from the Federal Deposit Insurance Corporation-Insured Commercial Banks data.

${ }^{7}$ As long as additional credit access doesn't enable an inefficient firm to stay in the market when it would otherwise exit (Aghion et al. 2019). 
lenders of agricultural loans as price-takers, i.e., they take the interest rate as given as they compete for creditworthy borrowers.

The lender's presumed objective is to maximize return on loans subject to acceptable risk, and Featherstone et al. (2006) note that credit risk is the primary source of risk to financial institutions. ${ }^{8}$ When the marginal cost (including the probability of default and loss given default) of giving the full value of the requested loan exceeds the given interest rate, lenders may face excess demand for agricultural loans. Even in otherwise competitive markets, gaps may exist between the borrower's desired credit and the lender's willingness to provide credit which results in credit rationing. The gaps may be due to such things as government usury laws, endogenous risk, and/or imperfect information in the functioning of the credit markets (Stiglitz and Weiss, 1981). When that occurs, the lender maximizes its profit by lending less than the amount sought by the farmer to maximize the farm's short-run profit. That may also decrease the farm's TFP.

\section{Empirical models}

Empirically, we use direct credit access measures (the amount of credit farmers accessed from all sources or just from commercial banks) and indirect credit access measures (representing the financial health of farmers and lenders which can determine the amount of credit farmers receive). Thus, the connection between our theoretical framework and empirical analysis is through the amount of the external loan granted or through indirect indicators that influence how much credit access farmers have. It connects the short-run and long-run farm models with the lender model, and it connects the reduced-form empirical model to the theoretical framework by means of the credit access measure(s).

A positive estimated relationship between residual returns to resources and the credit access measure(s) in the empirical model implies that limited credit access restricts the firm's ability to achieve maximum short-run profit. An estimated positive relationship between TFP and the credit access measure(s) implies that limited credit access is also constraining TFP and possibly long-run profit.

Our theoretical framework is developed for the representative firm (or a firm typical of those operating in the industry) while our empirical analysis is conducted using state-level data. We focus on the agricultural production sector and treat states as though they were price-taking cost-minimizing firms, a hypothesis previously not rejected by empirical testing (Lim and Shumway, 1992). We ignore farmer heterogeneity because such information is lacking in most of our state-level data.

\subsection{TFP model}

In our reduced-form state-level TFP models, we examine the relationship between TFP and credit access for the representative farmer while controlling for other factors found in prior literature (e.g., Huffman and Evenson, 2006; Jin and Huffman, 2016; Villavicencio et al., 2013) to have a significant impact on agricultural TFP. We augment the productivity model of Sabasi and Shumway (2018) by incorporating credit access measure(s) and an output gap measure to capture the effects of business cycles. ${ }^{9}$ The model we estimate for the 48 contiguous U.S. states is

$$
Y_{i t}=X_{i t} \beta+\tau_{t}+\mu_{i}+u_{i t}
$$

\footnotetext{
${ }^{8}$ To maximize returns on loans by granting credit to farmers with low probability of default $(P D)$ and low loss given default $(L G D)$, credit scoring models are often used by the FCS and other lending institutions to determine the amount of loan to grant. Durguner and Katchova (2011) note that PD can be estimated by farmers' creditworthiness. LGD measures the impact on the institution if the farmer fails to service the debt (Featherstone et al., 2006). This is a cost to the lender.

${ }^{9}$ Output gap is a measure of the difference between real actual and real potential GDP.
} 
where $Y$ is $\ln (T F P), X$ is the matrix of the logarithms of time-varying regressors including credit access measures, $\tau$ is time fixed effects, $\mu$ is the matrix of time-invariant regressors (regional dummy variables), $u$ is a zero-mean random disturbance term, $i$ and $t$ are the state and year, respectively. There are $\mathrm{K}$ regressors, and $\beta$ is $\mathrm{Kx} 1$. The matrix $X$ includes credit access measure(s), the within-state stock of public agricultural research investments, the stock of public agricultural research spill-in from other states, the stock of public extension investments, farm operator's education level, rural healthcare access, the ratio of family labor to total labor; terms of trade (ratio of aggregate output price to aggregate input price), output gap, annual total precipitation, growing degree days, damaging degree days, 30-year rolling average temperature, and 30-year rolling average annual total rainfall. Public agricultural research and extension variables are included as proxies for (possibly non-neutral) technology shifters. Justification for the other regressors is provided in the next section.

We estimate equation (1) using two direct credit access measures, real farm sector total debt per farm and real agricultural production loans per farm, respectively, as base models. Real total farm debt is a comprehensive measure of all agricultural debt acquired by the farm while real agricultural production loans per farm are non-farmland/real estate debt acquired by farms from commercial banks for production and is re-evaluated annually. These measures are similar to several used in prior microlevel studies. For example, Rahaman (2011) used short-term bank loans and overdrafts/total liabilities as a measure of access to a bank credit facility while Foltz (2004) and Moro and Fink (2013) used credit received and Gatti and Love (2008) used presence and absence of an overdraft facility and line of credit (the latter was also used by Sufi, 2009) as credit access measures. Using a direct credit access measure provides a more statistically powerful measure of financial constraints than do indirect measures based on the financial health of lenders and borrowers (Sufi, 2009).

As initial robustness checks, we re-estimate equation (1) using two direct and two indirect credit access measures. The direct credit access measures used in the robustness checks are limited to loans from commercial banks: real agricultural loans (farmland plus production loans) per bank office and real agricultural loans per farm. Due to the high correlation between the measures $(0.80)$, we enter each measure of direct credit access into the estimation separately. These direct credit access measures indicate the average amount of credit per office supplied to farms by lenders and how much credit, on average, each farm accessed from commercial banks.

For indirect measures, we use the real value of farm assets per farm as a measure of the financial health of farmers and commercial banks' real bank net income per bank office as a measure of the financial health of lenders. Both indirect measures are included in the same estimation equation.

Farm assets have been previously used as a measure of farm access to credit (e.g., Ciaian et al., 2012; Bierlen and Featherstone, 1998; Hartarska and Nadolnyak 2012). Farm assets, especially the value of farmland, are often used as collateral in securing high valued loans (Witte et al., 2015).

Real bank net income per bank office is a major determinant of agricultural lenders' financial health (Briggeman et al., 2009a), and is determined in part by farmers' ability to repay their loans. For example, during the mid-1980s farm financial crisis, the failure by farmers to service their debt resulted in the FCS and agricultural banks charging off nearly $\$ 5$ billion in bad loans (Briggeman et al., 2009a). This was accompanied by increased failures of agricultural banks, accounting for $41 \%$ of the insured commercial banks that failed in 1984 (Calorimis et al., 1986).

For additional robustness checks, we (a) use the USDA TFP change measures as the dependent variable, ${ }^{10}(\mathrm{~b})$ exclude time fixed effects, (c) include a time trend (which would allow nonspurious

\footnotetext{
${ }^{10}$ The O'Donnell (2012) TFP numbers are a Lowe index which is theoretically superior to the USDA measures. O'Donnell's numbers satisfy all of the basic axioms from index theory (e.g., proportionality, transitivity, and circularity); for details, see O'Donnell (2018, Chapter 8). The TFP numbers produced by the USDA ERS and used by Jin and Huffman (2016) are a multilateral chain-linked Caves-Christensen-Diewert (1982) Malmquist index that do not satisfy the circularity property and so are not fully consistent with index theory (Shumway et al., 2016). We include the USDA measures as a robustness check because of their frequent use in productivity research.
} 
estimation of credit access if all data are stationary), (d) estimate the more compact productivity model of Jin and Huffman (2016) with the addition of credit access variables, and (e) determine whether the impact of credit access is sensitive to average farm size.

\subsection{Residual returns to resources models}

We also examine the impact of both base credit access variables on residual returns to unpaid labor and land. The same regressors are included in these models as in the TFP models. Robustness checks are conducted for these models using the other two direct access measures and the two indirect access measures.

\section{Data and Estimation Methods}

We use the same panel data set as Sabasi and Shumway (2018), augmented with credit access variables and an output gap measure. Our data are for the 48 contiguous states for the years 1966-2003. In robustness checks, we also use USDA's (USDA-ERS, 2013a) TFP indices in place O'Donnell's (2012) TFP indices as the dependent variable,

Residual (net) returns to unpaid labor and land are calculated as revenue plus direct government payments less labor and land costs. Revenue (including direct government payments) and cost data are from the USDA-ERS (USDA, 2013c).

Annual state-level data on total farm sector debt and the number of farms data are from the U.S. Department of Agriculture (USDA-ERS, 2013b). ${ }^{11}$ Nominal farm sector debt is converted to real farm sector debt using the Consumer Price Index (CPI). ${ }^{12}$ CPI data are from Shiller's (2016) website. Net returns to unpaid labor and net returns to unpaid labor and land are calculated as revenue plus direct government payments less the respective costs. Revenue (including direct government payments) and cost data are from the USDA-ERS (2013c).

Data on nominal commercial agricultural loans (farmland and agricultural production loans) are from the Federal Deposit Insurance Corporation (FDIC, 2016a). These are aggregated data from individual financial reports filed by FDIC-insured commercial banks and savings institutions. We convert the nominal values to real values following the same procedure used in deflating farm sector debt. Due to data limitations at the state level, we are only able to include loans provided by commercial banks. On average, commercial banks provided $32.89 \%$ of total farm sector debt (standard deviation $=6.75$ ) between 1960 and 2012. We divide the real agricultural loans by the total number of bank offices (institutions + branches) to get the supply side direct credit access measure, and we divide the real agricultural loans by the number of farms to get the demand side direct credit access measure. Nominal bank net income and the total number of bank offices data are from the Federal Deposit Insurance Corporation (FDIC, 2016b and 2016c, respectively). We convert the nominal bank net income to real values using the CPI as the deflator.

Farm assets for each state are measured as the real gross value of farm assets per farm. These data are from the Farm Balance Sheet from USDA-ERS (2013b) for the years 1960-2003 and are converted to 2003 dollars using the Bureau of Economic Analysis' chain-type GDP deflator obtained from the Federal Reserve Bank of St. Louis (2014). ${ }^{13}$

Public agricultural research stock data are from Jin and Huffman (2014) for 1966-1969 and from Jin and Huffman (2016) for 1970-2003. Public research spill-in is calculated using the public agricultural research data and spatial weights derived by Huffman (2015). The spatial weights are

\footnotetext{
${ }^{11}$ The USDA definition of farm is very generous (any operation that has agriculturally related annual sales greater than $\$ 1,000)$.

${ }^{12}$ As robustness checks, we use both the producer price index for farm products and the index of prices paid by farmers for inputs as deflators. Results remain robust. The farm products and input price indices data were obtained from the USDA-ERS (2018), and the producer price index for farm products came from the U.S. Department of Labor (USDL-BLS 2018).

${ }^{13}$ The state-level Farm Balance Sheet data series was suspended after 2003.
} 
calculated as a share of the value of agricultural production for each state in the sixteen geoclimatic regions relative to the value of all agricultural production for all states in the region. ${ }^{14}$ Public research spill-in for state $i$ is then calculated as the sum of the weighted public agricultural research stock for all other states, except state $i$, in the same geo-climatic region. The stock of public agricultural extension is calculated as the weighted average of the most recent 5 years of full-time-equivalent professional extension staff using exponentially declining weights. All three variables are expected to have a positive impact on productivity.

Healthcare access is proxied by Medical Doctors (MDs) per 10,000 population in rural counties of each state. County-level data on the number of MDs and population in each state are from the Bureau of Health Professions, National Center for Health Workforce Analysis (2013). For the identification of rural counties, the Urban Influence Code (UIC) developed by the USDA-ERS (2013d) which divides counties into metropolitan counties and nonmetropolitan (rural) counties is used. State-level data for MDs per 10,000 population is then calculated as a simple average of total MDs in all rural counties in each state per 10,000 population. Farmers' education level is approximated by an index of weighted average weekly working hours across various education levels and types of employment for each state. The index constructed by Liu et al. (2009) was updated by Sabasi and Shumway (2018) using data from Ball (2013). Both healthcare access and education are included as human capital measures. Human capital influences farmers' adoption and use of new technology, and technical change is the main driver of agricultural productivity so these variables are expected to have a positive impact.

Family-to-total labor data and terms of trade (ratio of aggregate output price to input price) are calculated using state-level data from the USDA-ERS (2013a). We include the family-to-total labor ratio as a self-sufficiency measure. We do not have a hypothesis on the sign of this variable. Hired labor may free up family labor to focus more on managing the farm, and they may be more experienced in carrying out activities they are hired to do than family labor, in which cases the impact could be positive. However, farmers may experience a moral hazard problem by relying more on hired labor which could cause the impact to be negative.

Terms of trade are included as a measure of farmers' ability to invest in costly new innovations which in turn have an impact on productivity. We do not have a hypothesis on the sign of this variable either. While an increase in input price, which implies a decrease in terms of trade, could induce input conservation and result in an increase in efficiency and hence productivity, it might also limit farmers' adoption of new technologies thereby any potential productivity increase.

The output gap measure is from the U.S. Bureau of Economic Analysis (USBEA, 2017) and the U.S. Congressional Budget Office (USCBO, 2017) accessed through the Federal Reserve Bank of St. Louis website and calculated as the difference between real actual and real potential output. It is included in the model as a measure of the business cycle. There is substantial evidence of linkages between the macroeconomy and agriculture (Ardeni and Freebairn, 2002). Macroeconomic policy and economic shocks (such as spikes in commodity prices) often impact farm sector outcomes (Abbott and McCalla, 2002). For instance, rising energy prices can negatively impact farm productivity and profit by increasing costs of transporting, heating, and cooling (Carter et al. 2011).

Weather data for each state (precipitation and temperature) are from the National Climatic Data Center (NCDC-NOAA, 2013). Precipitation is calculated as accumulated total per calendar year. Temperature is calculated as growing degree days - optimal crop growth temperature during the growing season (April-November each year) and damaging degree days-extreme heat days during the growing season. Both growing degree days and damaging degree days are calculated following Deschênes and Greenstone (2007). Growing degree days are measured by summing $\min \left\{\frac{T_{h}+T_{l}}{2}, T_{m}\right\}-T_{b}$ for each day, where $T_{h}$ is the day's maximum temperature, $T_{l}$ is the day's minimum temperature, $T_{m}$ is the upper bound growing temperature $\left(32^{\circ} \mathrm{C}\right)$, and $T_{b}$ is the lower

\footnotetext{
${ }^{14}$ The 16 geo-climatic regions are very similar to the USDA's 20 Land Resource Regions for the contiguous U.S. (see Huffman 2015).
} 
bound growing temperature $\left(8^{\circ} \mathrm{C}\right)$. Damaging degree days are calculated using the sum of $\left\{\frac{T_{h}+T_{l}}{2}-T_{m}\right\}$ for each day that $\frac{T_{h}+T_{l}}{2}>T_{m}$.

Lagged 30-year rolling averages (starting from 1936) for precipitation and temperature are used as proxies for agro-climatic conditions (agro-precipitation and agro-temperature). Agrotemperature is calculated as the 30-year average temperature during the growing season from April to November, and agro-precipitation is calculated as the 30 -year average total annual rainfall. Monthly averages for each state are from NCDC-NOAA.

The logic for including the weather variables is that productivity can be positively affected by favorable weather conditions through an upward shift in the realized production frontier and negatively affected by unfavorable weather conditions through a downward shift in the frontier. The logic for including climate measures is that, while the weather is random, systematic climatic changes are not. Hence, producers can respond by adopting innovations and/or modifying management and production practices that are more suitable to the changing climate, each of which could impact productivity and residual returns to resources.

Summary statistics are presented in Table 1.

We first conduct a series of diagnostic tests for model specification. We test for autocorrelation and heteroskedasticity using a Wooldridge test (Wooldridge, 2002) and a Modified Wald test (Baum, 2000), respectively, for both the TFP and the residual returns to resources models. Results, presented in Table 2, show that we cannot reject the presence of either heteroskedasticity or autocorrelation. Additionally, we perform the Hausman specification test to determine whether to use a random or fixed-effects panel data estimator. Results, presented in the same table, support using a fixed-effects estimator for both TFP models and both residual returns to resources models.

Consistent with prior studies examining the U.S. agricultural TFP (Huffman and Evenson, 2006; Jin and Huffman, 2016; Villavicencio et al., 2013), we use regional fixed effects in the estimation of each model. ${ }^{15} \mathrm{We}$ also include year fixed effects. We correct for both heteroskedasticity and autocorrelation in our estimation of the TFP models by using the Prais-Winsten panelcorrected standard errors (PCSE) estimator with AR(1) autocorrelation (Beck and Katz, 1995).

One of the main challenges in empirical estimation of finance and growth models is identification. That is, does access to finance improve productivity or does improvement in productivity improve access to finance? Endogeneity, which could emanate from the simultaneity problem would imply that $E\left(X_{i t} \varepsilon_{i t}\right) \neq 0$. If endogeneity exists, OLS estimation is generally biased and inconsistent.

We argue that credit access is exogenous to the TFP model. This is because technical change (increased output per unit of input and the main driver of TFP) is driven by a farmer's access to internal or external funds. Further, credit access is found to motivate farmers to improve their efficiency to ensure repayment capability (e.g., Blancard et al., 2006). As an empirical check to the logical argument that external finance is exogenous in the TFP models, we conduct the Hayashi endogeneity test (Hayashi, 2000). ${ }^{16}$ Results of the endogeneity test presented in Table 2 show that we fail to reject the null hypothesis of no endogeneity in both TFP models.

\footnotetext{
${ }^{15}$ We use regional fixed effects rather than state fixed effects for the following reasons: states within the same region share similar federal and state agricultural science and economic policies (Huffman and Evenson, 2006), and regional fixed effects conserve degrees of freedom and reduce collinearity. A similar approach has been used in related studies (e.g., Huffman and Evenson, 2006; Villavicencio et al., 2013; Jin and Huffman, 2016). The USDA Economic Research Service regions used in this study are Appalachian, Corn Belt, Delta States, Lake States, Mountain, Northeast, North Plains, Pacific, Southeast, and Southern Plains. The Corn Belt is the base region in the estimations.

${ }^{16}$ If the variables in the model are cointegrated, then the least squares estimators will be consistent even if the explanatory variables are correlated with the error terms. Because of our relatively short data series and the low power of cointegration tests for short data spans (Pedroni 2004), we do not test for nonstationary or cointegration. Rather, we rely on time series tests provided by prior studies of the U.S. agricultural production with longer time spans. They have generally found similar data to be nonstationary and cointegrated (e.g., Makki, Tweeten and Thraen 1999; Alston et al. 2011; Andersen and Song 2013). Anticipating similar results for each of our regressors and equations, model design would be the same as if all variables are stationary except that no time trend would be included (Lim and Shumway 1997).
} 
Table 1. Summary statistics

\begin{tabular}{|c|c|c|c|c|c|}
\hline Variable & Unit & Mean & $\begin{array}{l}\text { Standard } \\
\text { Deviation }\end{array}$ & $\begin{array}{l}\text { Minimum } \\
\text { Value }\end{array}$ & $\begin{array}{l}\text { Maximum } \\
\text { Value }\end{array}$ \\
\hline $\begin{array}{l}\text { Total factor productivity (O’Donnell, } \\
\text { 2012) }\end{array}$ & Index & 1.021 & 0.295 & 0.422 & 2.155 \\
\hline Total factor productivity (USDA, 2013a) & Index & 0.843 & 0.239 & 0.338 & 1.790 \\
\hline $\begin{array}{l}\text { Real returns to unpaid labor and land } \\
\text { per farm }\end{array}$ & $2009 \$ 1,000$ & 33.681 & 32.022 & -20.000 & 330.000 \\
\hline Real total debt per farm & $2003 \$ 1,000$ & 109.334 & 71.042 & 14.410 & 499.400 \\
\hline $\begin{array}{l}\text { Real (commercial) production loans per } \\
\quad \text { farm }\end{array}$ & $2003 \$ 1,000$ & 23.481 & 24.744 & 0.000 & 221.379 \\
\hline Real (commercial) loans per bank office & $2003 \$ 1,000$ & $2,023.180$ & $2,194.326$ & 1.000 & $10,837.000$ \\
\hline Real (commercial) loans per farm & $2003 \$ 1,000$ & 32.484 & 26.541 & 0.188 & 224.001 \\
\hline Real farm assets per farm & $2003 \$ 1,000$ & 615.986 & 474.463 & 94.066 & $11,629.068$ \\
\hline Real bank net income per bank office & $2003 \$ 1,000$ & $2,769.926$ & $1,606.895$ & 1.000 & $24,400.990$ \\
\hline Public research investment & $\$ M$ & 16.234 & 14.233 & 1.040 & 101.167 \\
\hline Public research spill-in & $\$ M$ & 67.571 & 34.152 & 6.300 & 171.737 \\
\hline Extension & $\begin{array}{l}\text { FTE prof. } \\
\text { staff }\end{array}$ & 142.397 & 99.326 & 0.028 & 562.310 \\
\hline Education & Index & 2.981 & 0.503 & 1.561 & 3.830 \\
\hline Healthcare access & Index & 12.537 & 5.259 & 4.757 & 37.318 \\
\hline Family-to-total labor ratio & Index & 0.697 & 0.163 & 0.112 & 0.934 \\
\hline Terms of trade & Index & 1.212 & 0.312 & 0.570 & 2.689 \\
\hline Output Gap & Index & -0.713 & 2.227 & -6.228 & 4.786 \\
\hline Precipitation & $\mathrm{cm}$ & 36.531 & 15.061 & 5.370 & 80.580 \\
\hline Growing degree days & ${ }^{\circ} \mathrm{F}$ days & 2318.038 & 720.188 & 1152.947 & 4456.675 \\
\hline Damaging degree days & ${ }^{\circ} \mathrm{F}$ days & 16.730 & 29.891 & 0.00001 & 235.083 \\
\hline Agro-temperature & ${ }^{\circ} \mathrm{F}$ & 60.868 & 6.486 & 50.878 & 75.769 \\
\hline Agro-precipitation & $\mathrm{cm}$ & 35.657 & 13.764 & 8.331 & 60.842 \\
\hline
\end{tabular}

Notes: Real returns data were adjusted by adding |Minimum Value|+1 to all observations before taking logarithms for estimation.

Thus, we rule out identification as a problem in the TFP models and estimate equation (1) following the procedure outlined above.

While the credit access measures are expected to be exogenous in explaining productivity, they are unlikely to be exogenous in explaining residual returns to resources. Because banks consider the farm's profits and financial health when making loan decisions, a farmer's access to credit may be affected by the farm's residual returns to resources which leads to a reverse causality issue.

Thus, based on a clear expectation that credit access variables are endogenous in explaining short-run farm profit, we use an IV/GMM estimator to estimate the residual returns to resources models (Baum et al., 2003). This estimator allows for both endogenous and exogenous regressors and assumes exogeneity of a set of instruments. Following Baum et al. (2003), we partition the matrix of regressors into endogenous variables, $X_{1}$, and exogenous variables, $X_{2}$. We further partition the instruments $Z$ into included instruments, $Z_{1}$, and excluded instruments, $Z_{2}$ (where included instruments are the same as exogenous regressors): 
Table 2. Data diagnostic tests for TFP and residual returns to resources models

\begin{tabular}{|c|c|c|c|c|c|c|}
\hline \multirow[b]{3}{*}{ Diagnostic Test } & \multirow[b]{3}{*}{ Distribution } & \multirow[b]{3}{*}{ Null Hypothesis } & \multicolumn{4}{|c|}{ Test Statistic ( $P$-value) } \\
\hline & & & \multicolumn{2}{|c|}{ TFP (O’Donnell) } & \multicolumn{2}{|c|}{ Residual Returns to Labor and Land } \\
\hline & & & $\begin{array}{c}\text { Real Total } \\
\text { Debt per Farm }\end{array}$ & $\begin{array}{l}\text { Real Production } \\
\text { Loans per Farm }\end{array}$ & $\begin{array}{c}\text { Real Total } \\
\text { Debt per Farm }\end{array}$ & $\begin{array}{l}\text { Real Production } \\
\text { Loans per Farm }\end{array}$ \\
\hline \multirow[t]{2}{*}{ Wooldridge (test for autocorrelation) } & \multirow[t]{2}{*}{$F(1,47)$} & \multirow[t]{2}{*}{ No first-order autocorrelation } & 33.886 & 49.375 & 28.872 & 34.435 \\
\hline & & & $(0.000)$ & $(0.000)$ & $(0.000)$ & $(0.000)$ \\
\hline \multirow{2}{*}{$\begin{array}{l}\text { Modified Wald (test for heteroske- } \\
\text { dasticity) }\end{array}$} & \multirow[t]{2}{*}{$\chi^{2}(48)$} & \multirow[t]{2}{*}{$\sigma_{i}^{2}=\sigma^{2}, \forall i$} & 892.690 & 830.480 & 3012.270 & 3066.360 \\
\hline & & & $(0.000)$ & $(0.000)$ & $(0.000)$ & $(0.000)$ \\
\hline \multirow{2}{*}{$\begin{array}{l}\text { Hausman (test for regional FE vs. } \\
\text { RE) }\end{array}$} & \multirow[t]{2}{*}{$\chi^{2}(13)$} & \multirow[t]{2}{*}{ Difference in coefficients not systematic } & 92.940 & 91.990 & 85.830 & 95.500 \\
\hline & & & $(0,000)$ & $(0.000)$ & $(0.000)$ & $(0.000)$ \\
\hline \multirow[t]{2}{*}{ Endogeneity test for TFP model } & \multirow[t]{2}{*}{$\chi^{2}(1)$} & \multirow{2}{*}{$\begin{array}{l}\text { Variable can be treated as exogenous in } \\
\text { the model }\end{array}$} & 2.840 & 0.005 & & \\
\hline & & & $(0.092)$ & (0.946) & & \\
\hline \multicolumn{7}{|l|}{$\begin{array}{l}\text { Valid/strong instruments tests for } \\
\text { returns to resources model: }\end{array}$} \\
\hline \multirow{2}{*}{$\begin{array}{l}\text { Under-identification (Kleibergen- } \\
\text { Paap) }\end{array}$} & \multirow[t]{2}{*}{$\chi^{2}(2)$} & \multirow[t]{2}{*}{ Structural equation is under-identified } & & & 129.408 & 20.576 \\
\hline & & & & & $(0.000)$ & $(0.000)$ \\
\hline Weak identification (Cragg-Donald) & $\begin{array}{l}\text { Wald F (Critical F: } \\
\text { 13.91) }\end{array}$ & Instruments are weak & & & 4820.992 & 889.500 \\
\hline \multirow{2}{*}{$\begin{array}{l}\text { Over-identifying restrictions } \\
\text { (Hansen J) }\end{array}$} & \multirow[t]{2}{*}{$\chi^{2}(1)$} & \multirow{2}{*}{$\begin{array}{l}\text { Instruments are valid, and excluded } \\
\text { instruments are correctly excluded }\end{array}$} & & & 1.234 & 1.298 \\
\hline & & & & & $(0.540)$ & $(0.523)$ \\
\hline
\end{tabular}

Notes: $\sigma^{2}$ is residual variance, $\mathrm{FE}$ is fixed effects, and $\mathrm{RE}$ is random effects. $P$ values are in parentheses.

Endogeneity test (Hayashi 2000, pp. 218-221) is computed as the difference between two Sargan statistics.

For the endogenous regressor, real total debt per farm, the excluded instruments are lag(Real total debt per farm), lag(Extension), and lag(Education); for real production loans per farm, they are lag(Real production

loans per farm), lag(Extension), and lag(Education), all in logarithms. 


$$
\begin{aligned}
& \text { Regressors } X=\left[\begin{array}{ll}
X_{1} & X_{2}
\end{array}\right]=\left[\begin{array}{ll}
X_{1} & Z_{1}
\end{array}\right]=\left[\begin{array}{l}
\text { Endogenous Exogenous }
\end{array}\right] \\
& \text { Instruments } Z=\left[\begin{array}{ll}
Z_{1} & Z_{2}
\end{array}\right]=[\text { Included Excluded }]
\end{aligned}
$$

Exogenous regressors (included instruments) are all variables from equation (1) except the credit access variables.

The residual returns to resources models include the lag of the endogenous credit access regressor $\left(X_{1}\right)$ along with $\ln (\text { Extension })_{\text {it-1 }}$ and $\ln (\text { Education })_{\text {it- } 1}$ as excluded instruments $\left(Z_{2}\right)$. The amount of total debt (or production loans) the farm accessed the previous year could impact the farm's ability to take on more debt or production loans. Thus, it could affect the following year's credit access for the representative farmer. Previous studies find that farmers with more education tend to have more precise risk assessments and adopt more sophisticated risk management tools (Sherrick et al., 2004). Hence, farmers' previous access to extension staff and more education are expected to enhance their knowledge of credit opportunities and risks involved in taking on additional debt. The instruments are taken from the previous period so are temporally exogenous to, although not necessarily uncorrelated with, the current period's value of real total debt and production loans per farm.

The set of $\mathrm{P}$ instruments gives a set of $\mathrm{P}$ sample moment conditions:

$$
\bar{g}(\widehat{\beta})=\frac{1}{n} Z^{\prime} \widehat{u}=\frac{1}{n} Z^{\prime}(y-X \beta)
$$

where $\bar{g}(\widehat{\beta})$ is a $P \times 1$ vector of sample moment conditions, $\mathrm{Z}$ is an $N \times P$ vector of instruments, $\widehat{u}$ is an $N \times 1$ estimate of the vector of residuals obtained from the initial consistent estimator. Since our equation is overidentified, i.e., $\mathrm{P}>\mathrm{K}$, we minimize the following objective function:

$$
J(\widehat{\beta})=n \bar{g}(\widehat{\beta}) W^{\prime} \bar{g}(\widehat{\beta})
$$

where $\mathrm{W}$ is a robust $P \times P$ weighting matrix (Baum et al., 2003). Thus, the GMM estimator is

$$
\widehat{\beta}_{G M M}=\left(X^{\prime} Z W Z^{\prime} X\right)^{-1} X^{\prime} Z W Z^{\prime} y
$$

We compute robust standard errors to find the variance-covariance matrix that is consistent in the presence of heteroscedasticity and serial correlation.

Results for tests of whether these instruments are valid and whether they are strong or weak instruments are presented for both base models in Table 2. The Kleibergen-Paap test in Stata rejects the null hypothesis that the structural equation is under-identified, which means that we do not find evidence that the instruments are irrelevant. Although no $P$ value can be computed for our Cragg-Donald statistic, a high value of the F-statistic in the weak identification test suggests the instruments are not weak. The over-identifying restrictions hypothesis is not rejected in either model by the Hansen J test. Thus, we proceed under the assumption that our chosen instruments are strong and valid (exogenous) predictors of the credit access measures. ${ }^{17}$

\section{Results}

TFP estimation results are presented in Table 3. They include estimates for the base models and several robustness checks. Except as noted, statistical significance is evaluated at the 0.05 level.

The base model with real agricultural debt per farm is reported in column 2 . The elasticity parameter of interest, real debt per farm, is 0.17 and statistically significant. The base model with

\footnotetext{
${ }^{17}$ While the evidence from our logical arguments and statistical tests gives us reasonable confidence in treating credit access as exogenous in explaining both productivity and residual returns to resources, we acknowledge that it only applies to the state-level data we are using. It is more likely that access to credit and farm productivity (or residual returns to farm resources) are jointly determined at the farm level due to common unobserved factors such as managerial ability.
} 
Table 3. TFP model estimates and robustness checks

\begin{tabular}{|c|c|c|c|c|c|c|c|}
\hline \multirow[b]{2}{*}{ Variable } & \multirow[b]{2}{*}{$\begin{array}{l}\text { Real Total } \\
\text { Debt per } \\
\text { Farm }\end{array}$} & \multirow[b]{2}{*}{$\begin{array}{l}\text { Real } \\
\text { Production } \\
\text { Loans per } \\
\text { Farm }\end{array}$} & \multicolumn{2}{|c|}{$\begin{array}{l}\text { Other Direct Credit } \\
\text { Access Measures }\end{array}$} & \multirow[b]{2}{*}{$\begin{array}{l}\text { Indirect } \\
\text { Credit } \\
\text { Access }\end{array}$} & \multicolumn{2}{|c|}{ TFP (USDA) } \\
\hline & & & $\begin{array}{c}\text { Real } \\
\text { Loans per } \\
\text { Bank }\end{array}$ & $\begin{array}{l}\text { Real } \\
\text { Loans per } \\
\text { Farm }\end{array}$ & & $\begin{array}{l}\text { Real Total } \\
\text { Debt per } \\
\text { Farm }\end{array}$ & $\begin{array}{c}\text { Real } \\
\text { Production } \\
\text { Loans per } \\
\text { Farm }\end{array}$ \\
\hline In(Real total debt per & $0.1720^{\star \star \star}$ & & & & & $0.1920^{\star \star \star}$ & \\
\hline farm) & $(0.0170)$ & & & & & $(0.0153)$ & \\
\hline In(Real production & & $0.0126^{\star \star}$ & & & & & $0.0216^{\star \star \star}$ \\
\hline loans per farm) & & $(0.0053)$ & & & & & $(0.0055)$ \\
\hline In(Real loans per & & & $0.0225^{\star \star \star}$ & & & & \\
\hline bank office) & & & $(0.0058)$ & & & & \\
\hline In(Real loans per & & & & $0.0268^{\star \star \star}$ & & & \\
\hline farm) & & & & $(0.0073)$ & & & \\
\hline $\begin{array}{l}\text { In(Real farm assets } \\
\text { per }\end{array}$ & & & & & $0.1020^{\star * *}$ & & \\
\hline farm) & & & & & $(0.0163)$ & & \\
\hline In(Real bank income & & & & & $0.0129^{\star *}$ & & \\
\hline per bank office) & & & & & $(0.0053)$ & & \\
\hline \multirow[t]{2}{*}{ In(Public research) } & $0.0766^{\star \star \star}$ & $0.1040^{\star \star \star}$ & $0.1010^{\star * *}$ & $0.0992^{\star \star \star}$ & $0.1000^{\star * *}$ & $0.0505^{\star \star \star}$ & $0.0771^{\star \star \star}$ \\
\hline & $(0.0095)$ & $(0.0099)$ & $(0.0097)$ & $(0.0098)$ & $(0.0096)$ & $(0.0087)$ & $(0.0091)$ \\
\hline In(Public research & $0.0943^{\star \star \star}$ & $0.0998^{\star \star \star}$ & $0.1010^{\star \star \star}$ & $0.0994^{\star \star \star}$ & $0.0926^{\star * \star}$ & $0.0797^{\star \star \star}$ & $0.0843^{\star \star \star}$ \\
\hline spill-in) & $(0.0123)$ & $(0.0127)$ & $(0.0128)$ & $(0.0128)$ & $(0.0128)$ & $(0.0111)$ & $(0.0111)$ \\
\hline \multirow[t]{2}{*}{ In(Extension) } & 0.0007 & -0.0037 & -0.0047 & -0.0030 & -0.0006 & 0.0001 & -0.0063 \\
\hline & $(0.0069)$ & $(0.0074)$ & $(0.0073)$ & $(0.0074)$ & $(0.0080)$ & $(0.0065)$ & $(0.0072)$ \\
\hline \multirow[t]{2}{*}{ In(Education) } & -0.1300 & -0.1280 & -0.0653 & -0.1160 & -0.1250 & $-0.1870^{\star \star \star}$ & $-0.1860^{\star \star}$ \\
\hline & $(0.0846)$ & $(0.0868)$ & $(0.0913)$ & $(0.0879)$ & $(0.0869)$ & $(0.0719)$ & $(0.0768)$ \\
\hline \multirow[t]{2}{*}{ In(Healthcare access) } & -0.0179 & 0.0122 & 0.0083 & 0.0078 & -0.0133 & -0.0022 & $0.0332^{\star \star}$ \\
\hline & $(0.0163)$ & $(0.0167)$ & $(0.0171)$ & $(0.0169)$ & $(0.0167)$ & $(0.0149)$ & $(0.0155)$ \\
\hline $\begin{array}{l}\text { In(Family-to-total } \\
\text { labor }\end{array}$ & $-0.2080^{\star \star \star}$ & $-0.2670^{\star \star \star}$ & $-0.2850^{\star \star \star}$ & $-0.2700^{\star \star \star}$ & $-0.2330^{\star \star \star}$ & $-0.1950^{\star \star \star}$ & $-0.2720^{\star \star \star}$ \\
\hline ratio) & $(0.0210)$ & $(0.0216)$ & $(0.0241)$ & $(0.0221)$ & $(0.0216)$ & $(0.0190)$ & $(0.0199)$ \\
\hline \multirow[t]{2}{*}{ In(Terms of trade) } & $-0.2380^{\star \star \star}$ & $-0.2870^{\star \star \star}$ & $-0.2930^{\star \star \star}$ & $-0.2820^{\star \star \star}$ & $-0.2590^{\star \star \star}$ & $-0.2620^{\star \star \star}$ & $-0.3400^{\star \star \star}$ \\
\hline & $(0.0400)$ & $(0.0428)$ & $(0.0441)$ & $(0.0424)$ & $(0.0410)$ & $(0.0403)$ & $(0.0443)$ \\
\hline \multirow[t]{2}{*}{ Output Gap } & 0.0039 & -0.0013 & -0.00002 & -0.0011 & $-0.0100^{\star \star \star}$ & 0.0044 & -0.0002 \\
\hline & $(0.0051)$ & $(0.0050)$ & $(0.0052)$ & $(0.0051)$ & $(0.0028)$ & $(0.0044)$ & $(0.0043)$ \\
\hline \multirow[t]{2}{*}{ In(Precipitation) } & $0.0536^{\star \star \star}$ & $0.0537^{\star \star \star}$ & $0.0528^{\star \star \star}$ & $0.0539^{\star \star \star}$ & $0.0541^{\star \star \star}$ & $0.0486^{\star \star \star}$ & $0.0487^{\star \star \star}$ \\
\hline & $(0.0149)$ & $(0.0151)$ & $(0.0151)$ & $(0.0151)$ & $(0.0147)$ & $(0.0152)$ & $(0.0157)$ \\
\hline In(Growing degree & $0.0950^{\star \star \star}$ & $0.1050^{\star \star \star}$ & $0.0980^{\star \star \star}$ & $0.1040^{\star \star \star}$ & $0.1130^{\star \star \star}$ & $0.0660^{\star \star \star}$ & $0.0778^{\star \star \star}$ \\
\hline days) & $(0.0228)$ & $(0.0244)$ & $(0.0239)$ & $(0.0242)$ & $(0.0239)$ & $(0.0203)$ & $(0.0218)$ \\
\hline
\end{tabular}


Table 3. (Continued)

\begin{tabular}{|c|c|c|c|c|c|c|c|}
\hline \multirow[b]{2}{*}{ Variable } & \multirow[b]{2}{*}{$\begin{array}{l}\text { Real Total } \\
\text { Debt per } \\
\text { Farm }\end{array}$} & \multirow[b]{2}{*}{$\begin{array}{l}\text { Real } \\
\text { Production } \\
\text { Loans per } \\
\text { Farm }\end{array}$} & \multicolumn{2}{|c|}{$\begin{array}{l}\text { Other Direct Credit } \\
\text { Access Measures }\end{array}$} & \multirow[b]{2}{*}{$\begin{array}{c}\text { Indirect } \\
\text { Credit } \\
\text { Access }\end{array}$} & \multicolumn{2}{|c|}{ TFP (USDA) } \\
\hline & & & $\begin{array}{l}\text { Real } \\
\text { Loans per } \\
\text { Bank }\end{array}$ & $\begin{array}{l}\text { Real } \\
\text { Loans per } \\
\text { Farm }\end{array}$ & & $\begin{array}{l}\text { Real Total } \\
\text { Debt per } \\
\text { Farm }\end{array}$ & $\begin{array}{c}\text { Real } \\
\text { Production } \\
\text { Loans per } \\
\text { Farm }\end{array}$ \\
\hline In(Damaging degree & $-0.0048^{\star \star \star}$ & $-0.0044^{\star *}$ & $-0.0046^{\star \star \star}$ & $-0.0045^{\star *}$ & $-0.0049^{\star * \star}$ & $-0.0047^{\star \star \star}$ & $-0.0038^{*}$ \\
\hline days) & $(0.0017)$ & $(0.0018)$ & $(0.0017)$ & $(0.0018)$ & $(0.0017)$ & $(0.0018)$ & $(0.0019)$ \\
\hline \multirow[t]{2}{*}{ In(Agro-temperature) } & $0.2730^{\star \star}$ & $0.4440^{\star * *}$ & $0.5230^{\star \star \star}$ & $0.4080^{\star * \star}$ & 0.2210 & $0.4830^{\star * \star}$ & $0.6400^{\star \star \star}$ \\
\hline & $(0.1360)$ & $(0.1320)$ & $(0.1320)$ & $(0.1360)$ & $(0.1470)$ & $(0.1160)$ & $(0.1080)$ \\
\hline \multirow[t]{2}{*}{ In(Agro-precipitation) } & $0.1710^{\star \star \star}$ & $0.1090^{\star \star \star}$ & $0.0920^{\star \star}$ & $0.1140^{\star \star \star}$ & $0.1820^{\star \star \star}$ & $0.1580^{\star \star \star}$ & $0.0968^{\star \star \star}$ \\
\hline & $(0.0377)$ & $(0.0402)$ & $(0.0409)$ & $(0.0403)$ & $(0.0392)$ & $(0.0336)$ & $(0.0353)$ \\
\hline \multirow[t]{2}{*}{ Intercept } & $-7.5710^{\star \star \star}$ & $-6.8830^{\star \star \star}$ & $-7.1520^{\star \star \star}$ & $-6.8160^{\star \star \star}$ & $-6.5920^{\star \star \star}$ & $-7.8840^{\star \star \star}$ & $-6.9830^{\star \star \star}$ \\
\hline & $(0.7270)$ & $(0.7380)$ & $(0.7400)$ & $(0.7500)$ & $(0.7530)$ & $(0.6470)$ & $(0.6360)$ \\
\hline $\mathrm{R}$ squared & 0.698 & 0.673 & 0.672 & 0.671 & 0.677 & 0.755 & 0.713 \\
\hline
\end{tabular}

Notes: With the exception of the last two models, we use O'Donnell's (2012) TFP index that satisfies all the basic axioms of index theory as the dependent variable. Total observations: 1824. Standard errors are in parentheses; ${ }^{\star} p<0.10,{ }^{\star \star} p<0.05,{ }^{\star \star \star} p<0.01$. Parameters are estimated using the Prais-Winsten panel-corrected standard errors (PCSE) estimator with AR(1) autocorrelation. Regional and time parameter estimates are suppressed.

real production loans per farm is reported in column 3 and provides a statistically significant credit access elasticity parameter of 0.01 . The positive and statistically significant estimates of credit access in both of the base models imply that increasing credit access is associated with an increase in TFP.

Our TFP model results remain robust across several alternative measures of credit access and two measures of TFP. Estimates using real commercial agricultural loans per bank office as the credit access measure are presented in column 4 . With a positive and statistically significant relationship between real loans per bank office and TFP, the real agricultural loans per bank office elasticity are 0.02 . When real commercial agricultural loans per farm are used as a measure of credit access (column 5), the relation remains positive and statistically significant and the elasticity is similar (0.03).

Parameter estimates using indirect credit access measures of the financial health of farmers and lenders are presented in column 6 . The estimate for real farm assets per farm is positive and statistically significant with an elasticity of 0.10 . The estimate for real bank net income per bank office (the lenders' liquidity measure) is also positive and statistically significant with an elasticity of 0.01 .

Base model parameter estimates using USDA's (USDA-ERS, 2013a) TFP indices are reported in columns 7 and 8 . The credit access measures are both positive and statistically significant with elasticity estimates of 0.19 and 0.02 .

Base model parameter estimates without time fixed effects are reported in columns 2 and 3 of Table 4, parameter estimates with a time trend in place of time fixed effects are reported in columns 4 and 5, and parameter estimates based on the Jin and Huffman (2016) model are reported in columns 6 and 7 of that table. Credit access measures are positive and statistically significant in four of the six models (one significant only at the 0.10 level) with elasticities ranging from 0.01 to 0.22 .

We lack data about the heterogeneity of firms, but we do have a measure of average farm size in each state for each year-real farm assets per farm. To determine whether our findings are 
Table 4. Additional TFP robustness checks

\begin{tabular}{|c|c|c|c|c|c|c|}
\hline \multirow[b]{2}{*}{ Variable } & \multicolumn{2}{|c|}{ Without Time Fixed Effects } & \multicolumn{2}{|c|}{ Time Trend Without Time Fixed Effects } & \multicolumn{2}{|c|}{ Jin-Huffman Model With Credit Access } \\
\hline & $\begin{array}{l}\text { Real Total Debt per } \\
\text { Farm }\end{array}$ & $\begin{array}{l}\text { Real Production Loans per } \\
\text { Farm }\end{array}$ & $\begin{array}{l}\text { Real Total Debt per } \\
\text { Farm }\end{array}$ & $\begin{array}{c}\text { Real Production Loans per } \\
\text { Farm }\end{array}$ & $\begin{array}{l}\text { Real Total Debt per } \\
\text { Farm }\end{array}$ & $\begin{array}{c}\text { Real Production Loans per } \\
\text { Farm }\end{array}$ \\
\hline In(Real total & $0.0621^{\star \star \star}$ & & $0.1210^{\star \star \star}$ & & $0.2170^{\star \star \star}$ & \\
\hline debt per farm) & $(0.0230)$ & & $(0.0235)$ & & $(0.0188)$ & \\
\hline In(Real production & & 0.0042 & & $0.0099^{*}$ & & 0.0014 \\
\hline loans per farm) & & $(0.0056)$ & & $(0.0055)$ & & $(0.0053)$ \\
\hline \multirow[t]{2}{*}{ In(Public research) } & $0.1540^{\star \star \star}$ & $0.1540^{\star * *}$ & $0.1060^{\star \star \star}$ & $0.1200^{\star \star \star}$ & $0.0630^{*}$ & $0.0762^{\star \star}$ \\
\hline & $(0.0142)$ & $(0.0136)$ & $(0.0117)$ & $(0.0108)$ & $(0.0342)$ & $(0.0368)$ \\
\hline In(Public research & $0.1970^{\star * *}$ & $0.1770^{\star * *}$ & $0.1140^{\star \star \star}$ & $0.1090^{\star \star \star}$ & $0.1010^{\star \star \star}$ & $0.1360^{* * *}$ \\
\hline spill-in) & $(0.0205)$ & $(0.0209)$ & $(0.0155)$ & $(0.0148)$ & $(0.0132)$ & $(0.0148)$ \\
\hline \multirow[t]{2}{*}{ In(Extension) } & -0.0091 & -0.0089 & -0.0052 & -0.0054 & -0.0485 & $-0.1980^{\star}$ \\
\hline & $(0.0080)$ & $(0.0081)$ & $(0.0072)$ & $(0.0075)$ & $(0.1040)$ & $(0.1140)$ \\
\hline In(Public research) & & & & & 0.0027 & 0.0121 \\
\hline${ }^{*} \ln ($ Extension $)$ & & & & & $(0.0067)$ & $(0.0074)$ \\
\hline \multirow[t]{2}{*}{ In(Education) } & -0.1170 & -0.0755 & $-0.3240^{\star \star \star}$ & $-0.1920^{\star \star}$ & & \\
\hline & $(0.0857)$ & $(0.0852)$ & $(0.0931)$ & $(0.0879)$ & & \\
\hline \multirow[t]{2}{*}{$\begin{array}{l}\text { In(Healthcare } \\
\text { access) }\end{array}$} & $0.0933^{\star \star \star}$ & $0.0882^{\star \star \star}$ & -0.0172 & 0.0057 & & \\
\hline & $(0.0239)$ & $(0.0230)$ & $(0.0197)$ & $(0.0189)$ & & \\
\hline In(Family-to-total & $-0.2100^{\star * *}$ & $-0.2360^{\star \star \star}$ & $-0.1690^{\star \star \star}$ & $-0.2220^{\star \star \star}$ & & \\
\hline labor ratio) & $(0.0228)$ & $(0.0229)$ & $(0.0240)$ & $(0.0236)$ & & \\
\hline \multirow[t]{2}{*}{ In(Terms of trade) } & $-0.1980^{\star * *}$ & $-0.2140^{\star \star *}$ & $-0.0880^{*}$ & $-0.1380^{\star \star \star}$ & & \\
\hline & $(0.0470)$ & $(0.0465)$ & $(0.0462)$ & $(0.0466)$ & & \\
\hline Output Gap & -0.0034 & -0.0037 & -0.0015 & -0.0025 & & \\
\hline
\end{tabular}


Table 4. (Continued)

\begin{tabular}{|c|c|c|c|c|c|c|}
\hline \multirow[b]{2}{*}{ Variable } & \multicolumn{2}{|c|}{ Without Time Fixed Effects } & \multicolumn{2}{|c|}{ Time Trend Without Time Fixed Effects } & \multicolumn{2}{|c|}{ Jin-Huffman Model With Credit Access } \\
\hline & $\begin{array}{l}\text { Real Total Debt per } \\
\text { Farm }\end{array}$ & $\begin{array}{c}\text { Real Production Loans per } \\
\text { Farm }\end{array}$ & $\begin{array}{c}\text { Real Total Debt per } \\
\text { Farm }\end{array}$ & $\begin{array}{c}\text { Real Production Loans per } \\
\text { Farm }\end{array}$ & $\begin{array}{l}\text { Real Total Debt per } \\
\text { Farm }\end{array}$ & $\begin{array}{c}\text { Real Production Loans per } \\
\text { Farm }\end{array}$ \\
\hline & $(0.0031)$ & $(0.0031)$ & $(0.0029)$ & $(0.0028)$ & & \\
\hline \multirow[t]{2}{*}{$\ln$ (Precipitation) } & $0.0507^{\star \star \star}$ & $0.0522^{\star \star \star}$ & $0.0524^{\star \star \star}$ & $0.0547^{\star \star \star}$ & & \\
\hline & $(0.0189)$ & $(0.0187)$ & $(0.0176)$ & $(0.0176)$ & & \\
\hline In(Growing degree & $0.1630^{\star \star \star}$ & $0.1670^{\star \star \star}$ & $0.1270^{\star \star \star}$ & $0.1420^{\star \star \star}$ & & \\
\hline days) & $(0.0379)$ & $(0.0360)$ & $(0.0353)$ & $(0.0333)$ & & \\
\hline In(Damaging & $-0.0143^{\star \star \star}$ & $-0.0141^{\star \star *}$ & $-0.0137^{\star \star *}$ & $-0.0138^{\star \star \star}$ & & \\
\hline degree days) & $(0.0027)$ & $(0.0026)$ & $(0.0024)$ & $(0.0023)$ & & \\
\hline In(Agro- & $0.7010^{\star \star \star}$ & $0.7050^{\star \star \star}$ & $0.4060^{\star *}$ & $0.5150^{\star \star \star}$ & & \\
\hline temperature) & $(0.1650)$ & $(0.1530)$ & $(0.1660)$ & $(0.1460)$ & & \\
\hline In(Agro- & $0.1730^{\star \star \star}$ & $0.1360^{\star * *}$ & $0.1490^{\star \star \star}$ & $0.0979 \star \star$ & & \\
\hline precipitation) & $(0.0459)$ & $(0.0452)$ & $(0.0447)$ & $(0.0432)$ & & \\
\hline \multirow[t]{2}{*}{ Trend } & & & $0.0127^{\star \star \star}$ & $0.0090^{\star \star \star}$ & $0.0109^{\star \star \star}$ & $0.0101^{\star \star \star}$ \\
\hline & & & $(0.0019)$ & $(0.0017)$ & $(0.0004)$ & $(0.0004)$ \\
\hline \multirow[t]{2}{*}{ Intercept } & $-11.8600^{\star \star \star}$ & $-10.7700^{\star \star \star}$ & $-8.4110^{\star * \star}$ & $-7.7940^{\star \star \star}$ & $-5.5390^{\star \star \star *}$ & $-4.0180^{\star \star \star}$ \\
\hline & $(0.9650)$ & $(0.9780)$ & $(0.8260)$ & $(0.7830)$ & $(0.5250)$ & $(0.5800)$ \\
\hline $\begin{array}{l}\text { Number of observa- } \\
\text { tions }\end{array}$ & 1824 & 1824 & 1824 & 1824 & 1824 & 1824 \\
\hline $\mathrm{R}$ squared & 0.575 & 0.588 & 0.592 & 0.603 & 0.571 & 0.501 \\
\hline
\end{tabular}

Notes: Standard errors are in parentheses; ${ }^{\star} p<0.10,{ }^{\star \star} p<0.05,{ }^{\star \star \star} p<0.01$. Parameters are estimated using the Prais-Winsten panel-corrected standard errors (PCSE) estimator with AR(1) autocorrelation standard errors are in parentheses. 
sensitive to farm size, we include real farm assets per farm and its interaction with the credit access variable as additional regressors in each of the TFP models using direct credit access measures as the final TFP robustness checks. Results are reported in Table 5. All credit access measures remain positive, statistically significant, and with elasticities at the mean of farm size similar to those when farm size is omitted (ranging from 0.01 to 0.17 ). The interaction terms are all negative and statistically significant, implying that the adverse impact of limited credit access decreases as average farm size increases.

Both base models and all robustness checks show a consistently positive relationship between farmer's credit access and TFP, and most are statistically significant. These results are consistent with Lambert and Bayda (2005) who found a positive relationship between intermediate debt and both technical and scale efficiency for North Dakota. They are also consistent with Mugera and Nyambane (2015) who found a positive relationship between short-term debt structure and both technical and scale efficiency for broadacre farms in Western Australia.

Other parameter estimates with a consistently positive and statistically significant association with TFP across models are public research investments, public research spill-in, precipitation, growing degree days, agro-temperature (with one exception), and agro-precipitation. When included in the direct credit access models, real farm assets per farm also have a consistently positive and statistically significant association with TFP across models. Consistently negative and statistically significant parameter associations across models occur with family-to-total labor ratio, terms of trade, and damaging degree days (two are significant at the 0.10 level). Most of these results are consistent with previous research (e.g., Sabasi and Shumway, 2018).

Although credit access is consistently estimated to have a positive effect on agricultural productivity, the elasticity estimates from many of the models are quite small. To determine the relative impact that credit access has had on productivity growth for our data set, we contrast it to the impact of public research. We compute the estimated difference in TFP between the minimum and maximum values of credit access (or public research investments and spill-ins) with all other regressors held at their mean values using each model in Table 3. The mean impact of credit access is nearly two-thirds the impact of public research (with a range from 0.24 to 1.38 ). Besides varying across models, the impact would also vary across states and over time and could be expected to be greater for smaller than for larger farms.

Thus, credit access is estimated to be a binding constraint to TFP maximization (and long-run profit in competitive markets with prices used as the aggregation weights as in these data) even in the U.S. agriculture. A plausible explanation of this positive relationship between credit access and TFP could be that as farmers' credit access increases, they adopt more advanced technologies, meet operating expenses, and adjust their scale and mix of inputs and outputs in order to operate in the economic region of competitive production. Further, an increase in credit access could enable farmers to hire consultants or specialized labor which could increase technical efficiency and consequently TFP.

Parameter estimates for the residual returns to unpaid labor and land models are presented in Table 6. They include estimates for the base models and three robustness checks. The base model with real total debt per farm is reported in column 2 and provides a credit access elasticity estimate of 0.20 that is statistically significant. The base model with real production loans per farm is reported in column 3 with a statistically significant elasticity estimate is 0.05 . The positive and statistically significant estimates of credit access in both of the base models imply that increasing credit access is associated with an increase in residual returns to unpaid labor and land.

Our residual returns model results remain robust across alternative direct measures of credit access. Estimates using real commercial agricultural loans per bank office as the credit access measure are presented in column 4 with a statistically significant elasticity of 0.07 . When real commercial agricultural loans per farm are used as a measure of credit access (column 5), the relation remains positive and statistically significant with a similar elasticity of 0.09 . 
Table 5. TFP direct credit access and firm size model robustness checks

\begin{tabular}{|c|c|c|c|c|c|c|}
\hline \multirow[b]{2}{*}{ Variable } & \multirow[b]{2}{*}{$\begin{array}{c}\text { Real Total } \\
\text { Debt per } \\
\text { Farm }\end{array}$} & \multirow[b]{2}{*}{$\begin{array}{l}\text { Real Production } \\
\text { Loans per Farm }\end{array}$} & \multicolumn{2}{|c|}{$\begin{array}{l}\text { Other Direct Credit } \\
\text { Access Measures }\end{array}$} & \multicolumn{2}{|c|}{ TFP (USDA) } \\
\hline & & & $\begin{array}{l}\text { Real Loans } \\
\text { per Bank }\end{array}$ & $\begin{array}{l}\text { Real Loans } \\
\text { per Farm }\end{array}$ & $\begin{array}{l}\text { Real Total } \\
\text { Debt per } \\
\text { Farm }\end{array}$ & $\begin{array}{l}\text { Real Production } \\
\text { Loans per Farm }\end{array}$ \\
\hline \multirow[t]{2}{*}{$\begin{array}{l}\text { In(Real total debt } \\
\quad \text { per farm) }\end{array}$} & $0.525^{\star \star \star}$ & & & & $0.564^{\star \star \star}$ & \\
\hline & $(0.0904)$ & & & & $(0.0867)$ & \\
\hline $\begin{array}{l}\text { In(Real total debt } \\
\text { per farm) }\end{array}$ & $-0.0575^{\star \star *}$ & & & & $-0.0607^{\star \star \star}$ & \\
\hline $\begin{array}{l}\text { * In(Real farm } \\
\text { assets per farm) }\end{array}$ & $(0.0142)$ & & & & $(0.0133)$ & \\
\hline \multirow[t]{2}{*}{$\begin{array}{l}\text { In(Real production } \\
\text { loans per farm) }\end{array}$} & & $0.240^{\star \star \star}$ & & & & $0.262^{\star \star \star}$ \\
\hline & & $(0.0517)$ & & & & $(0.0498)$ \\
\hline $\begin{array}{l}\text { In(Real production } \\
\text { loans per farm) }\end{array}$ & & $-0.0361^{\star \star \star}$ & & & & $-0.0385^{\star \star \star}$ \\
\hline $\begin{array}{l}\text { * In(Real farm } \\
\text { assets per farm) }\end{array}$ & & $(0.00802)$ & & & & $(0.00761)$ \\
\hline \multirow[t]{2}{*}{$\begin{array}{l}\text { In(Real loans per } \\
\text { bank office) }\end{array}$} & & & $0.186^{\star \star *}$ & & & \\
\hline & & & $(0.0536)$ & & & \\
\hline $\begin{array}{l}\text { In(Real loans per } \\
\text { bank office) }\end{array}$ & & & $-0.0259^{\star \star \star}$ & & & \\
\hline $\begin{array}{l}\text { * In(Real farm } \\
\text { assets per farm) }\end{array}$ & & & $(0.00826)$ & & & \\
\hline \multirow[t]{2}{*}{$\begin{array}{l}\text { In(Real loans per } \\
\quad \text { farm) }\end{array}$} & & & & $0.278^{\star \star \star}$ & & \\
\hline & & & & $(0.0597)$ & & \\
\hline $\begin{array}{l}\text { In(Real loans per } \\
\quad \text { farm) }\end{array}$ & & & & $-0.0403^{\star \star \star}$ & & \\
\hline $\begin{array}{l}{ }^{*} \text { In(Real farm } \\
\text { assets per farm) }\end{array}$ & & & & $(0.00923)$ & & \\
\hline \multirow[t]{2}{*}{$\begin{array}{l}\text { In(Real farm } \\
\quad \text { assets per farm) }\end{array}$} & $0.671^{\star \star \star}$ & $0.446^{\star \star \star}$ & $0.273^{\star \star \star}$ & $0.501^{\star \star \star}$ & $0.710^{\star \star \star}$ & $0.484^{\star \star \star}$ \\
\hline & $(0.164)$ & $(0.0767)$ & $(0.0551)$ & $(0.0926)$ & $(0.153)$ & $(0.0725)$ \\
\hline \multirow[t]{2}{*}{ In(Public research) } & $0.0743^{\star \star *}$ & $0.0882^{\star \star *}$ & $0.0889^{\star \star \star *}$ & $0.0867^{\star \star \star}$ & $0.0486^{\star \star \star}$ & $0.0593^{\star \star \star}$ \\
\hline & $(0.00945)$ & $(0.00972)$ & $(0.00946)$ & $(0.00965)$ & $(0.00867)$ & $(0.00913)$ \\
\hline \multirow{2}{*}{$\begin{array}{l}\text { In(Public research } \\
\text { spill-in) }\end{array}$} & $0.0966^{\star \star \star}$ & $0.0931^{\star \star \star}$ & $0.0882^{\star \star \star *}$ & $0.0929^{\star \star \star}$ & $0.0822^{\star * *}$ & $0.0770^{\star \star \star}$ \\
\hline & $(0.0125)$ & $(0.0121)$ & $(0.0122)$ & $(0.0121)$ & $(0.0114)$ & $(0.0106)$ \\
\hline \multirow[t]{2}{*}{ In(Extension) } & 0.000385 & -0.000714 & -0.00171 & -0.000386 & -0.000501 & -0.00194 \\
\hline & $(0.00702)$ & $(0.00769)$ & $(0.00755)$ & $(0.00776)$ & $(0.00669)$ & $(0.00754)$ \\
\hline In(Education) & $-0.167^{\star \star}$ & $-0.174^{\star \star}$ & -0.0551 & $-0.159^{*}$ & $-0.226^{\star \star \star}$ & $-0.236^{\star \star \star}$ \\
\hline
\end{tabular}


Table 5. (Continued)

\begin{tabular}{|c|c|c|c|c|c|c|}
\hline \multirow[b]{2}{*}{ Variable } & \multirow[b]{2}{*}{$\begin{array}{l}\text { Real Total } \\
\text { Debt per } \\
\text { Farm }\end{array}$} & \multirow[b]{2}{*}{$\begin{array}{l}\text { Real Production } \\
\text { Loans per Farm }\end{array}$} & \multicolumn{2}{|c|}{$\begin{array}{l}\text { Other Direct Credit } \\
\text { Access Measures }\end{array}$} & \multicolumn{2}{|c|}{ TFP (USDA) } \\
\hline & & & $\begin{array}{l}\text { Real Loans } \\
\text { per Bank }\end{array}$ & $\begin{array}{l}\text { Real Loans } \\
\text { per Farm }\end{array}$ & $\begin{array}{l}\text { Real Total } \\
\text { Debt per } \\
\text { Farm }\end{array}$ & $\begin{array}{l}\text { Real Production } \\
\text { Loans per Farm }\end{array}$ \\
\hline & $(0.0850)$ & $(0.0840)$ & $(0.0868)$ & $(0.0842)$ & $(0.0745)$ & $(0.0756)$ \\
\hline \multirow{2}{*}{$\begin{array}{l}\text { In(Healthcare } \\
\text { access) }\end{array}$} & -0.0241 & -0.0147 & -0.00936 & -0.0172 & -0.00908 & -0.000321 \\
\hline & $(0.0169)$ & $(0.0164)$ & $(0.0169)$ & $(0.0165)$ & $(0.0158)$ & $(0.0151)$ \\
\hline \multirow{2}{*}{$\begin{array}{l}\text { In(Family-to-total } \\
\text { labor ratio) }\end{array}$} & $-0.208^{\star \star \star}$ & $-0.239^{\star \star \star}$ & $-0.263^{\star \star \star}$ & $-0.246^{\star \star \star}$ & $-0.194^{\star \star \star}$ & $-0.233^{\star \star \star}$ \\
\hline & $(0.0214)$ & $(0.0213)$ & $(0.0239)$ & $(0.0220)$ & $(0.0197)$ & $(0.0196)$ \\
\hline \multirow[t]{2}{*}{ In(Terms of trade) } & $-0.250^{\star \star \star}$ & $-0.296^{\star \star \star}$ & $-0.299^{\star \star \star}$ & $-0.294^{\star \star \star}$ & $-0.267^{\star \star \star}$ & $-0.338^{\star \star \star}$ \\
\hline & $(0.0404)$ & $(0.0426)$ & $(0.0440)$ & $(0.0424)$ & $(0.0406)$ & $(0.0434)$ \\
\hline \multirow[t]{2}{*}{ Output Gap } & 0.00413 & $-0.00730^{\star}$ & -0.00527 & -0.00677 & 0.00446 & $-0.00782^{\star \star}$ \\
\hline & $(0.00501)$ & $(0.00412)$ & $(0.00428)$ & $(0.00413)$ & $(0.00436)$ & $(0.00361)$ \\
\hline \multirow[t]{2}{*}{ In(Precipitation) } & $0.0536^{\star \star \star}$ & $0.0538^{\star \star \star}$ & $0.0512^{\star \star \star}$ & $0.0538^{\star \star \star}$ & $0.0491^{\star \star \star}$ & $0.0491^{\star \star \star}$ \\
\hline & $(0.0149)$ & $(0.0150)$ & $(0.0151)$ & $(0.0149)$ & $(0.0151)$ & $(0.0155)$ \\
\hline \multirow{2}{*}{$\begin{array}{l}\text { In(Growing degree } \\
\text { days) }\end{array}$} & $0.100^{\star \star \star}$ & $0.111^{\star \star \star}$ & $0.0933^{\star * *}$ & $0.108^{\star \star \star}$ & $0.0723^{\star \star \star}$ & $0.0833^{\star \star \star}$ \\
\hline & $(0.0227)$ & $(0.0230)$ & $(0.0235)$ & $(0.0229)$ & $(0.0204)$ & $(0.0204)$ \\
\hline \multirow{2}{*}{$\begin{array}{l}\text { In(Damaging } \\
\text { degree days) }\end{array}$} & $-0.00463^{\star \star \star}$ & $-0.00405^{\star \star}$ & $-0.00437^{\star \star \star}$ & $-0.00407^{\star \star}$ & $-0.00472^{\star \star *}$ & $-0.00345^{\star}$ \\
\hline & $(0.00168)$ & $(0.00175)$ & $(0.00169)$ & $(0.00174)$ & $(0.00174)$ & $(0.00187)$ \\
\hline \multirow{2}{*}{$\begin{array}{l}\text { In(Agro-tempera- } \\
\text { ture) }\end{array}$} & 0.226 & 0.157 & 0.220 & 0.141 & $0.435^{\star \star \star}$ & $0.328^{\star \star \star}$ \\
\hline & $(0.145)$ & $(0.139)$ & $(0.138)$ & $(0.141)$ & $(0.127)$ & $(0.116)$ \\
\hline \multirow{2}{*}{$\begin{array}{l}\text { In(Agro-precipita- } \\
\text { tion) }\end{array}$} & $0.135^{\star \star \star}$ & $0.154^{\star \star \star}$ & $0.167^{\star \star \star}$ & $0.161^{\star \star \star}$ & $0.120^{\star \star \star}$ & $0.148^{\star \star \star}$ \\
\hline & $(0.0372)$ & $(0.0366)$ & $(0.0376)$ & $(0.0367)$ & $(0.0334)$ & $(0.0321)$ \\
\hline \multirow[t]{2}{*}{ Intercept } & $-11.35^{\star \star \star}$ & $-8.163^{\star \star \star}$ & $-7.351^{\star \star \star}$ & $-8.551^{\star \star \star}$ & $-11.89^{\star \star \star}$ & $-8.347^{\star \star \star}$ \\
\hline & (1.182) & $(0.793)$ & $(0.746)$ & $(0.850)$ & (1.092) & $(0.706)$ \\
\hline $\mathrm{R}$ squared & 0.704 & 0.699 & 0.697 & 0.697 & 0.757 & 0.757 \\
\hline
\end{tabular}

Notes: With the exception of the last two models, we use O'Donnell's (2012) TFP index that satisfies all the basic axioms of index theory as the dependent variable. Total observations: 1824 . Standard errors are in parentheses; ${ }^{\star} p<0.10,{ }^{\star \star} p<0.05,{ }^{\star \star \star} p<0.01$. Parameters are estimated using the Prais-Winsten panel-corrected standard errors (PCSE) estimator with AR(1) autocorrelation. Regional and time parameter estimates are suppressed.

Parameter estimates using indirect credit access measures of the financial health of farmers and lenders are presented in column 6 . The estimate for real farm assets per farm is positive with an elasticity of 0.08 but not statistically significant. The estimate for real bank net income per bank office (the lenders' liquidity measure) is negative with an elasticity of -0.05 and also not statistically significant.

Base residual return model parameter estimates with a time trend in place of time fixed effects are reported in columns 2 and 3 of Table 7, and parameter estimates based on the Jin and Huffman 
Table 6. Residual returns to unpaid labor and land model estimates and robustness checks

\begin{tabular}{|c|c|c|c|c|c|}
\hline \multirow[b]{2}{*}{ Variable } & \multirow[b]{2}{*}{$\begin{array}{l}\text { Real Total Debt } \\
\text { per Farm }\end{array}$} & \multirow[b]{2}{*}{$\begin{array}{l}\text { Real Production Loans } \\
\text { per Farm }\end{array}$} & \multicolumn{2}{|c|}{$\begin{array}{l}\text { Other Direct Credit Access } \\
\text { Measures }\end{array}$} & \multirow{2}{*}{$\begin{array}{l}\text { Indirect } \\
\text { Credit } \\
\text { Access }\end{array}$} \\
\hline & & & $\begin{array}{l}\text { Real Loans } \\
\text { per Bank }\end{array}$ & $\begin{array}{l}\text { Real Loans } \\
\text { per Farm }\end{array}$ & \\
\hline \multirow[t]{2}{*}{$\begin{array}{l}\text { In(Real total debt per } \\
\quad \text { farm) }\end{array}$} & $0.2040^{\star \star \star}$ & & & & \\
\hline & $(0.0674)$ & & & & \\
\hline \multirow[t]{2}{*}{$\begin{array}{l}\text { In (Real production loans } \\
\text { per farm) }\end{array}$} & & $0.0470^{\star \star}$ & & & \\
\hline & & $(0.0228)$ & & & \\
\hline \multirow[t]{2}{*}{$\begin{array}{l}\ln \text { (Real loans per bank } \\
\text { office) }\end{array}$} & & & $0.0720^{\star \star}$ & & \\
\hline & & & $(0.0284)$ & & \\
\hline \multirow[t]{2}{*}{ In(Real loans per farm) } & & & & $0.0875^{\star \star \star}$ & \\
\hline & & & & $(0.0302)$ & \\
\hline \multirow[t]{2}{*}{$\begin{array}{l}\text { In (Real farm assets per } \\
\text { farm) }\end{array}$} & & & & & 0.0772 \\
\hline & & & & & $(0.0735)$ \\
\hline \multirow[t]{2}{*}{$\begin{array}{l}\text { In (Real bank income per } \\
\text { bank office) }\end{array}$} & & & & & -0.0498 \\
\hline & & & & & $(0.0602)$ \\
\hline \multirow[t]{2}{*}{ In(Public research) } & 0.0960 & 0.0815 & 0.1090 & 0.0778 & 0.0851 \\
\hline & $(0.0831)$ & $(0.0882)$ & $(0.0873)$ & $(0.0886)$ & $(0.0854)$ \\
\hline \multirow[t]{2}{*}{ In(Public research spill-in) } & 0.1030 & -0.0055 & 0.0333 & -0.0159 & 0.0322 \\
\hline & $(0.1560)$ & $(0.1690)$ & $(0.1650)$ & $(0.1690)$ & $(0.1610)$ \\
\hline \multirow[t]{2}{*}{ In(Extension) } & $-0.0585^{\star \star \star}$ & $-0.0662^{\star * \star}$ & $-0.0677^{\star \star \star}$ & $-0.0593^{\star \star \star}$ & $-0.0742^{\star \star \star}$ \\
\hline & $(0.0198)$ & $(0.0203)$ & $(0.0207)$ & $(0.0203)$ & $(0.0210)$ \\
\hline \multirow[t]{2}{*}{ In(Education) } & -0.2390 & -0.0546 & -0.0009 & -0.0901 & -0.0113 \\
\hline & $(0.2240)$ & $(0.2280)$ & $(0.2270)$ & $(0.2250)$ & $(0.2320)$ \\
\hline \multirow[t]{2}{*}{ In(Healthcare access) } & $0.3930^{\star \star *}$ & $0.4180^{\star \star *}$ & $0.3990^{\star \star \star}$ & $0.3900^{\star \star \star}$ & $0.4380^{\star \star \star *}$ \\
\hline & $(0.1100)$ & $(0.1180)$ & $(0.1150)$ & $(0.1140)$ & $(0.1180)$ \\
\hline \multirow{2}{*}{$\begin{array}{l}\text { In(Family-to-total labor } \\
\text { ratio) }\end{array}$} & 0.1090 & 0.0257 & 0.0247 & 0.0317 & 0.0497 \\
\hline & $(0.0868)$ & $(0.0846)$ & $(0.0842)$ & $(0.0839)$ & $(0.0853)$ \\
\hline \multirow[t]{2}{*}{ In(Terms of trade) } & $0.7540^{\star \star \star}$ & $0.6690^{\star \star \star}$ & $0.6790^{\star \star \star}$ & $0.6740^{\star \star \star}$ & $0.7030^{\star \star *}$ \\
\hline & $(0.1150)$ & $(0.1180)$ & $(0.1170)$ & $(0.1170)$ & $(0.1180)$ \\
\hline \multirow[t]{2}{*}{ Output Gap } & $1.1820^{\star \star \star}$ & 0.0069 & $1.1730^{\star \star \star}$ & $1.1620^{\star \star \star}$ & $1.1470^{\star \star \star}$ \\
\hline & $(0.1610)$ & $(0.0141)$ & $(0.1620)$ & $(0.1620)$ & $(0.1690)$ \\
\hline \multirow[t]{2}{*}{ In(Precipitation) } & $0.0817^{*}$ & $0.0864^{*}$ & $0.0845^{\star}$ & $0.0831^{*}$ & $0.0874^{*}$ \\
\hline & $(0.0457)$ & $(0.0465)$ & $(0.0458)$ & $(0.0461)$ & $(0.0466)$ \\
\hline In(Growing degree days) & 0.1420 & 0.1060 & 0.0894 & 0.0984 & 0.1240 \\
\hline
\end{tabular}


Table 6. (Continued)

\begin{tabular}{|c|c|c|c|c|c|}
\hline \multirow[b]{2}{*}{ Variable } & \multirow[b]{2}{*}{$\begin{array}{l}\text { Real Total Debt } \\
\text { per Farm }\end{array}$} & \multirow[b]{2}{*}{$\begin{array}{l}\text { Real Production Loans } \\
\text { per Farm }\end{array}$} & \multicolumn{2}{|c|}{$\begin{array}{c}\text { Other Direct Credit Access } \\
\text { Measures }\end{array}$} & \multirow{2}{*}{$\begin{array}{l}\text { Indirect } \\
\text { Credit } \\
\text { Access }\end{array}$} \\
\hline & & & $\begin{array}{l}\text { Real Loans } \\
\text { per Bank }\end{array}$ & $\begin{array}{l}\text { Real Loans } \\
\text { per Farm }\end{array}$ & \\
\hline & $(0.1690)$ & $(0.1680)$ & $(0.1680)$ & $(0.1670)$ & $(0.1720)$ \\
\hline \multirow{2}{*}{$\begin{array}{l}\text { In(Damaging degree } \\
\text { days) }\end{array}$} & $-0.0165^{\star \star}$ & $-0.0153^{\star \star}$ & $-0.0145^{\star \star}$ & $-0.0145^{\star \star}$ & $-0.0161^{\star \star}$ \\
\hline & $(0.0073)$ & $(0.0073)$ & $(0.0074)$ & $(0.0073)$ & $(0.0074)$ \\
\hline \multirow[t]{2}{*}{ In(Agro-temperature) } & $-8.4900^{\star \star}$ & $-9.3100^{\star \star *}$ & $-9.6540^{\star *}$ & $-7.7110^{*}$ & $-9.0300^{\star *}$ \\
\hline & $(3.6850)$ & $(4.0600)$ & $(3.9360)$ & $(4.0480)$ & $(4.0500)$ \\
\hline \multirow[t]{2}{*}{ In(Agro-precipitation) } & -0.8570 & -0.9740 & $-1.0110^{\star}$ & -0.8020 & $-1.0900^{*}$ \\
\hline & $(0.5890)$ & (0.6130) & $(0.5940)$ & $(0.6010)$ & $(0.6190)$ \\
\hline
\end{tabular}

Notes: Standard errors are in parentheses; ${ }^{*} p<0.10,{ }^{\star \star} p<0.05,{ }^{\star \star \star} p<0.01$. Parameters are estimated by IV/GMM with state and year fixed effects. For each endogenous regressor, the excluded instruments are lag(endogenous regressor), lag(Extension), and lag(Education), all in logarithms. State and time parameter estimates are suppressed.

(2016) model are reported in columns 4 and 5 of that table. All estimates of the credit access measures are positive with elasticities ranging from 0.01 to 0.19 . The estimates based on the Jin and Huffman (2016) model are both statistically significant. The estimate with time trend and real production loans per farm is significant only at the 0.10 level.

Other parameter estimates that have a consistently positive and significant association with residual returns to unpaid labor and land are terms of trade, output gap (with one exception), and precipitation (at the 0.10 level). Consistently negative and significant associations include damaging degree days and agro-temperature (one is significant at the 0.10 level). While several of these variables impact TFP and residual returns to resources differently, the qualitative impact of credit access does not.

The residual returns to resources models generally support the TFP models in this important way. Based on state-level data, even for American farmers, an increase in credit access is positively associated with an increase in both TFP and residual returns to resources and implies that farmers fail to maximize both short-run and long-run profits. Results from this study are consistent with those from prior studies which find that limited credit negatively impacts the U.S. farm output (e.g., Briggeman, et al., 2009b) and inputs used (e.g., Kumar et al., 2013), farm efficiency (Chavas and Aliber, 1993), and overall rural economic growth (Hartarska, et al., 2015).

\section{Conclusions and implications}

In this article, we examine the relationship between credit access and both the U.S. agricultural TFP and residual returns to resources using direct and indirect credit access measures. Our panel data set is state level for all 48 contiguous states for the period 1966-2003. By focusing on the U.S. and addressing TFP, our study is set apart from prior literature on limited credit access, most of which focus on developing countries or more narrowly within developed countries.

Results show that improved credit access is associated with an increase in both agricultural TFP and residual returns to resources. Our results are generally robust to a variety of changes in the base models, such as using alternative credit access measures and model specifications. We find strong evidence of a crucial linkage between access to external financing and improvements in agricultural productivity and of a crucial linkage between credit access and residual returns to resources. Our findings generally support the hypothesis that, similar to its impact on productivity in developing countries, increased credit access is positively associated with an increase in the U.S. 
Table 7. Additional residual return model robustness checks

\begin{tabular}{|c|c|c|c|c|}
\hline \multirow[b]{3}{*}{ Variable } & \multicolumn{4}{|c|}{ Residual Returns to Labor and Land } \\
\hline & \multicolumn{2}{|c|}{ Time Trend Without Time Fixed Effects } & \multicolumn{2}{|c|}{ Jin-Huffman Model With Credit Access } \\
\hline & $\begin{array}{l}\text { Real Total Debt } \\
\text { per Farm }\end{array}$ & $\begin{array}{l}\text { Real Production Loans } \\
\text { per Farm }\end{array}$ & $\begin{array}{l}\text { Real Total Debt } \\
\text { per Farm }\end{array}$ & $\begin{array}{c}\text { Real Production Loans } \\
\text { per Farm }\end{array}$ \\
\hline \multirow{2}{*}{$\begin{array}{l}\text { In(Real total debt per } \\
\quad \text { farm) }\end{array}$} & 0.0144 & & $0.1850^{\star \star \star}$ & \\
\hline & $(0.0547)$ & & $(0.0661)$ & \\
\hline \multirow{2}{*}{$\begin{array}{l}\text { In (Real production loans } \\
\text { per farm) }\end{array}$} & & $0.0409^{\star}$ & & $0.0597^{\star \star}$ \\
\hline & & $(0.0239)$ & & $(0.0253)$ \\
\hline \multirow[t]{2}{*}{ In(Public research) } & $0.1940^{\star \star}$ & $0.1900^{\star}$ & 0.0075 & 0.0103 \\
\hline & $(0.0982)$ & $(0.1000)$ & $(0.2180)$ & $(0.2250)$ \\
\hline \multirow{2}{*}{$\begin{array}{l}\text { In(Public research } \\
\text { spill-in) }\end{array}$} & $0.6500^{\star \star \star}$ & $0.6330^{\star \star \star}$ & -0.0389 & -0.1110 \\
\hline & $(0.1550)$ & $(0.1470)$ & $(0.1310)$ & $(0.1420)$ \\
\hline \multirow[t]{2}{*}{ In(Extension) } & -0.0319 & -0.0332 & -0.4710 & -0.4250 \\
\hline & $(0.0276)$ & $(0.0304)$ & $(0.5090)$ & $(0.539)$ \\
\hline \multirow{2}{*}{$\begin{array}{l}\text { In(Public research) } \\
{ }^{*} \ln (\text { Extension) }\end{array}$} & & & 0.0255 & 0.0220 \\
\hline & & & $(0.0328)$ & $(0.0346)$ \\
\hline \multirow[t]{2}{*}{ In(Education) } & $-0.5100^{\star \star \star}$ & $-0.5220^{\star \star \star}$ & & \\
\hline & $(0.1540)$ & $(0.1250)$ & & \\
\hline \multirow[t]{2}{*}{ In(Healthcare access) } & -0.0432 & -0.0504 & & \\
\hline & $(0.1030)$ & $(0.1040)$ & & \\
\hline \multirow{2}{*}{$\begin{array}{l}\text { In(Family-to-total labor } \\
\text { ratio) }\end{array}$} & 0.0993 & 0.0914 & & \\
\hline & $(0.1000)$ & $(0.0953)$ & & \\
\hline \multirow[t]{2}{*}{ In(Terms of trade) } & $0.6430^{\star \star *}$ & $0.6260^{\star \star \star}$ & & \\
\hline & $(0.1030)$ & $(0.1020)$ & & \\
\hline \multirow[t]{2}{*}{ Output Gap } & $0.0267^{\star \star \star}$ & $0.0265^{\star \star \star}$ & & \\
\hline & $(0.0041)$ & $(0.0040)$ & & \\
\hline \multirow[t]{2}{*}{ In(Precipitation) } & $0.1110^{\star \star}$ & $0.1080^{\star \star}$ & & \\
\hline & $(0.0486)$ & $(0.0484)$ & & \\
\hline \multirow[t]{2}{*}{ In(Growing degree days) } & $0.3240^{\star \star *}$ & $0.2950^{\star \star}$ & & \\
\hline & $(0.1400)$ & $(0.1390)$ & & \\
\hline \multirow{2}{*}{$\begin{array}{l}\text { In(Damaging degree } \\
\text { days) }\end{array}$} & $-0.0293^{\star \star \star}$ & $-0.0275^{\star \star \star}$ & & \\
\hline & $(0.0066)$ & $(0.0065)$ & & \\
\hline \multirow[t]{2}{*}{ In(Agro-temperature) } & $-12.5400^{\star \star \star}$ & $-12.0400^{\star \star \star}$ & & \\
\hline & $(4.4360)$ & $(4.5930)$ & & \\
\hline
\end{tabular}


Table 7. (Continued)

\begin{tabular}{|c|c|c|c|c|}
\hline \multirow[b]{3}{*}{ Variable } & \multicolumn{4}{|c|}{ Residual Returns to Labor and Land } \\
\hline & \multicolumn{2}{|c|}{ Time Trend Without Time Fixed Effects } & \multicolumn{2}{|c|}{ Jin-Huffman Model With Credit Access } \\
\hline & $\begin{array}{l}\text { Real Total Debt } \\
\text { per Farm }\end{array}$ & $\begin{array}{c}\text { Real Production Loans } \\
\text { per Farm }\end{array}$ & $\begin{array}{l}\text { Real Total Debt } \\
\text { per Farm }\end{array}$ & $\begin{array}{c}\text { Real Production Loans } \\
\text { per Farm }\end{array}$ \\
\hline \multirow[t]{2}{*}{ In(Agro-precipitation) } & $-1.7460^{\star \star}$ & $-1.6530^{\star *}$ & & \\
\hline & $(0.7100)$ & $(0.7140)$ & & \\
\hline \multirow[t]{2}{*}{ Trend } & 0.0039 & 0.0045 & & \\
\hline & $(0.0052)$ & $(0.0053)$ & & \\
\hline \multicolumn{5}{|l|}{ Intercept } \\
\hline Number of observations & 1776 & 1776 & 1776 & 1776 \\
\hline $\mathrm{R}$ squared & 0.132 & 0.136 & 0.302 & 0.292 \\
\hline
\end{tabular}

Notes: Standard errors are in parentheses; ${ }^{*} p<0.10,{ }^{\star \star} p<0.05,{ }^{\star \star \star} p<0.01$. Parameters are estimated using the Prais-Winsten panelcorrected standard errors (PCSE) estimator with AR(1) autocorrelation; standard errors are in parentheses.

agricultural productivity. In addition, its estimated impact is nearly two-thirds as great as that of public research investments and spill-ins over the range of our data. The estimated elasticity of credit access on productivity decreases as average farm size increases. Our findings imply that relaxing credit constraints to farmers could lead to increased agricultural productivity as well as short- and long-run profit.

Findings from this article have important policy implications. One implication is that increasing farmers' credit access could stimulate the U.S. agricultural productivity growth and long-run profit. Thus, programs such as the Farm Service Agency's Farm Loan Program that improve farmers' credit access can be expected to be beneficial for productivity growth. As found in previous research (e.g., Chava et al., 2013), this could be due to enabling young, small, and beginning farmers to adopt new innovations. Further, targeted, government-backed credit access may be an attractive policy solution to support farms pursuing local markets as a core competitive advantage (Bauman et al., 2018). The second policy implication is that risk mitigation programs, such as crop insurance, that improve farmers' creditworthiness, could be beneficial for agricultural TFP growth. As Maisashvili et al. (2020) highlight, agricultural lenders often require crop insurance as a condition to receive operating loans. One way to increase farmers' risk management ability is through improving their access to credit (Cafiero et al., 2007). While these policy implications are for the U.S., they could have broad applicability to both developed and developing countries where limited credit access slows productivity growth.

Our findings also raise a number of important questions. For example, is the high technical efficiency among large producers, as found in prior literature (e.g., Paul et al., 2004), at least partially due to the high debt concentration among these large producers? And, what is the relationship between access to external financing and observed economies of scale, firm growth, and concentration in agriculture?

Acknowledgments. The authors would like to thank Tristan D. Skolrud, Daegoon Lee, Johnson Gwatipedza, Jonathan K. Yoder, and Thomas L. Marsh for their helpful comments on earlier drafts. This project was supported by the Washington Agricultural Research Center and by the USDA National Institute of Food and Agriculture, Hatch grant WPN000275.

Author Contributions. Conceptualization, D.S., C.R.S; Methodology, D.S., C.R.S; Formal Analysis, D.S., C.R.S.; and L.K.; Data Curation, D.S., Writing-Original Draft, D.S., C.R.S., L.K.; Writing-Review and Editing, D.S., C.R.S; Supervision, C.R.S; Funding Acquisition, C.R.S.

Conflict of interest. Darlington Sabasi, C.R. Shumway, and Lyudmyla Kompaniyets declare none. 
Data availability statement. The data that support the findings of this study are openly available and all the links to data sources have been provided in the references section.

Financial support. Washington Agricultural Research Center and USDA National Institute of Food and Agriculture Hatch grant WPN000275.

\section{References}

Abbott, P., and A. McCalla. "Agriculture in the macroeconomy: Theory and measurement." Handbook of Agricultural Economics. B.L. Gardner and G.C. Rausser, eds., 2(Part A). Amsterdam: Elsevier B.V., 2002.

Aghion, P., A. Bergeaud, G. Cette, R. Lecat, and H. Maghin. "Coase lecture - The inverted-U relationship between credit access and productivity growth.” Economica 86(2019):1-31.

Alston, J.L., M.A. Andersen, S.J. James, and P.G. Pardey. "The economic returns to U.S. public agricultural research.” American Journal of Agricultural Economics 93(2011):1257-1277.

Andersen, M. A., and W. Song. "The economic impact of public agricultural research and development in the United States." Agricultural Economics 44(2013):287-295.

Ardeni, P.G., and J. Freebairn. “The macroeconomics of agriculture." Handbook of Agricultural Economics. B.L. Gardner and G.C. Rausser, eds., 2(Part A). Amsterdam: Elsevier, B.V., 2002.

Ball, V.E. “Detailed agricultural labor data by State, 1960-2004.” Unpublished. U.S. Department of Agriculture, Economic Research Service. Personal communication, 2013.

Ball, E., D. Schimmelpfenning, and S.L. Wang. "Is U.S. agricultural productivity growth slowing?" Applied Economic Perspectives and Policy 353(2013):435-450.

Barry, P.J., and L.J. Robison. “Agricultural finance: Credit, credit constraints, and consequences.” Handbook of Agricultural Economics. B.L. Gardner and G.C. Rausser (eds), 1A. Amsterdam: Elsevier B.V., 2001, pp. 513-571.

Baum, C.F., M.E. Schaffer, and S. Stillman. "Instrumental variables and GMM: Estimation and testing." Stata Journal 3(2003):1-31.

Baum, C.F. XTTEST3: Stata module to compute Modified Wald statistic for groupwise heteroskedasticity. Statistical Software Components S414801, Boston College Department of Economics, revised 05 July 2001, 2000.

Bauman, A., D.T. McFadden, and B.B.R. Jablonski. "The financial performance implications of differential marketing strategies: Exploring farms that pursue local markets as a core competitive advantage." Agricultural and Resource Economics Review 47(2018):477-504.

Beck, N., and J.N. Katz. "What to do (and not to do) with time-series cross-section data." American Political Science Review 893(1995):634-647.

Bierlen, R., and A.M. Featherstone. "Fundamental q, cash flow, and investment: Evidence from farm panel data." Review of Economics and Statistics 80(1998):427-435.

Blancard, S., J.P. Boussemart, and W.K. Kerstens. "Short-and long-run credit constraints in French agriculture: A directional distance function framework using expenditure-constrained profit functions." American Journal of Agricultural Economics 88(2006):351-364.

Briggeman, B.C., M.A. Gunderson, and B.A. Gloy. "The financial health of agricultural lenders." American Journal of Agricultural Economics 91(2009a):1406-1413.

Briggeman, B.C., C.A. Towe, and M.J. Morehart. "Credit constraints: Their existence, determinants, and implications for U.S. farm and nonfarm sole proprietorships.” American Journal of Agricultural Economics 91(2009b):275-289.

Bureau of Health Professions, National Center for Health Workforce Analysis. The area health resource file (ARHF), 2013. Internet site: http://ahrf.hrsa.gov/ (Accessed December 2013).

Butler, A.W., and J. Cornaggia. "Does access to finance improve productivity? Evidence from a natural experiment." Journal of Financial Economics 99, 184-203.

Cadot, J. "Collateral, bank monitoring and firm performance: the case of newly established wine farmers." Australian Journal of Agricultural and Resource Economics 57(2013):344-358.

Cafiero, C., F. Capitanio, A. Cioffi, and A. Coppola. "Risk and crisis management in the reformed european agricultural policy." Canadian Journal of Agricultural Economics 54(2007):419-441.

Calorimis, C.W., R.G. Hubbard, and J.H. Stock. "The farm debt crisis and public policy." Brookings Papers on Economic Activity 2(1986):441-478.

Carter, M.R., and P. Olinto. "Getting institutions right for whom? Credit constraints and the impact of property rights on the quantity and composition of investment." American Journal of Agricultural Economics 85(2003):173-186.

Carter, C.A., G.C. Rausser, and A. Smith. "Commodity booms and busts." Annual Review of Resources Economics 3(2011):87-118.

Caves, D., L. Christensen, and W. Diewert. "The economic theory of index numbers and the measurement of input, output, and productivity." Econometrica 50(1982):1393-1414. 
Chaddad, F., M. Cook, and T. Heckelei. "Testing for the presence of financing constraints in U.S. agricultural cooperatives: An investment behavior approach." Journal of Agricultural Economics 56(2005):385-97.

Chava, S., A. Oettl, A. Subramanian, and K.V. Subramanian. "Banking deregulation and innovation." Journal of Financial Economics 109(2013): 759-774.

Chavas, J.-P., and M. Aliber. "An analysis of economic efficiency in agriculture: A non-parametric approach." Journal of Agricultural and Resource Economics 18(1993):1-16.

Ciaian, P., and J. Fałkowski. "Access to credit, factor allocation and farm productivity: Evidence from the CEE transition economies.” Agricultural Finance Review 72(2012):22-47 Kancs, d'A.

Deschênes, O., and M. Greenstone. "The economic impacts of climate change: Evidence from agricultural output and random fluctuations in weather." American Economic Review 97(2007):354-385.

Dimitri, C., A. Effland, and N. Conklin. "The 20th century transformation of U.S. agriculture and farm policy." Economic Information Bulletin No. (EIB-3). USDA-ERS, Washington, DC, 2005. Internet site: http://www.ers.usda.gov/publications/ EIB3/EIB3.pdf.

Durguner, S., and A.L. Katchova. "Repayment capacity of farmers: A balanced panel data approach." Journal of Applied Economics and Policy 30(2011):14-30.

Fazzari, S.M., R.G. Hubbard, and B.C. Petersen. "Financing constraints and corporate investment." Brookings Papers on Economic Activity 1(1988):141-206.

Featherstone, A.M., L.M. Roessler, and P.J. Barry. "Determining the probability of default and risk-rating class for loans in the seventh farm credit district portfolio." Review of Agricultural Economics 281(2006):4-23.

Federal Deposit Insurance Corporation (FDIC). Historical statistics on banking (HSOB), commercial banks, commercial bank reports. Financial data - balance sheet (balances at year-end). CB11: Loans and leases, and CB12 Real estate loans, 2016a. Internet site: https://www.fdic.gov/hsob/SelectRpt.asp?EntryTyp=10\&Header=1 (Accessed January 2016).

Federal Deposit Insurance Corporation (FDIC). Financial data - income statement (year-to-date activity), 2016b. CB04: Net income.

Federal Deposit Insurance Corporation (FDIC). Institution and structure (balances at year-end), 2016c. CB01: Number of institutions, branches and total offices.

Federal Reserve Bank of St. Louis. Gross domestic product (Chain-type price index), 2014. Internet site: https://research. stlouisfed.org/fred2/series/B191RG3A086NBEA (Accessed January 2014).

Foltz, J.D. "Credit market access and profitability in Tunisian agriculture." Agricultural Economics 30(2004):229-240.

Gardner, B.L. and G.C. Rausser, eds. Handbook of Agricultural Economics, 1A. Amsterdam: Elsevier, B.V., 2001.

Gatti, R., and I. Love. "Does access to credit improve productivity?" Economics of Transition 61(2008):445-465 Evidence from Bulgarian firms.

Guirkinger, C., and S.R. Boucher. "Credit constraints and productivity in Peruvian agriculture." Agricultural Economics 39(2008):295-308.

Harris, J.M., J. Johnson, J. Dillard, R. Williams, and R. Dubman. “The Debt finance landscape for U.S. farming and farm businesses." Economic Research Service Report AIS-87(2009).

Hartarska, V., and D. Nadolnyak. "Financing constraints and access to credit in a postcrisis environment: Evidence from new farmers in Alabama." Journal of Agricultural and Applied Economics 44(2012):607-621.

Hartarska, V., D. Nadolnyak, and X. Shen. "Agricultural credit and economic growth in rural areas." Agricultural Finance Review 75(2015):302-312.

Hayashi, F. Econometrics. Princeton, NJ: Princeton University Press, 2000.

Hoppe, R.A. Structure and finances of US farms: Family farm report, 2014 edition. United States Department of Agriculture, Economic Research Service, 2014.

Huffman, W.E. Measuring public agricultural research capital and its impact on State agricultural productivity in the United States. Technology, Innovations and Economic Development: Essays in Memory of Robert E. Evenson. L. Singh, K.J. Joseph and D.K. Johnson, eds., SAGE Publications, 2015.

Huffman, W.E., and R.E. Evenson. "Do formula or competitive grant funds have greater impacts on State agricultural productivity?" American Journal of Agricultural Economics 88(2006):783-798.

Jin, Y., and Huffman, W.E.. Public agricultural productivity oriented research expenditures by State, 1927-2009. Personal communication, 2014.

Jin, Y., and W.E. Huffman. "Measuring public agricultural research and extension and estimating their impacts on agricultural productivity: New insights from U.S. evidence." Agricultural Economics 47(2016):15-31.

Key, N., C. Burns, and G. Lyons. "Financial conditions in the U.S. agricultural sector: Historical comparisons." EIB-211, U.S. Department of Agriculture, Economic Research Report, 2019.

Kumar, C.S., C.G. Turvey, and J.D. Kropp. "The impact of credit constraints on farm households: Survey results from India and China." Applied Economic Perspectives and Policy 35(2013):508-527.

Khanal, A.R., and O. Omobitan. "Rural finance, capital constrained small farms, and financial performance: findings from a primary survey." Journal of Agricultural and Applied Economics 52(2020):288-307. 
Lambert, D.K., and V.V. Bayda. “The impacts of farm financial structure on production efficiency.” Journal of Agricultural and Applied Economics 37(2005):277-289.

Lim, H., and C. R. Shumway. "Profit maximization, returns to scale, and measurement error." Review of Economics and Statistics 74(1992):430-438.

Lim, H., and C. R. Shumway. “Technical change and model specification: U.S. agricultural production.” American Journal of Agricultural Economics 79(1997):543-554.

Liu, Y., C.R. Shumway, R. Rosenman, and V.E. Ball "Productivity growth and convergence in US Agriculture: New cointegration panel data results." Applied Economics 43(2009):91-102.

MacKie-Mason, J.K. "Do firms care who provides their financing?" Asymmetric Information, Corporate Finance, and Investment. R G. Hubbard, ed. Chicago: Chicago University Press, 1990.

Maisashvili, A., H.L. Bryant, and I.P.H. Jones. "Implications of alternative crop insurance subsidies." Journal of Agricultural and Applied Economics 52(2020):240-263.

Makki, S.S., and L.G. Tweeten. "Investing in research and education versus commodity programs: Implications for agricultural productivity." Journal of Productivity Analysis 12(1999):77-94.

Mishra, A., C. Moss, and K. Erickson. "The role of credit constraints and government subsidies in farmland valuations in the U.S.: An options pricing model approach.” Empirical Economics 34(2008):285-97.

Moro, A., and Fink, M. "Loan managers' trust and credit access for SMEs." Journal of Banking \& Finance 37(2013):927-936.

Moss, B.C., and D.H. Suh. "Effect of compliance cost on the supply of bank credit to agriculture: A differential approach." American Journal of Agricultural Economics 102(2020):713-726.

Mugera, A.W., and G.G. Nyambane. "Impact of debt structure on production efficiency and financial perfomance of Broadacre farms in Western Australia." Australian Journal of Agricultural and Resource Economics 59(2015):208-224.

Myers, S.C., and N.S. Majluf. "Corporate financing and investment decisions when firms have information that investors do not have." Journal of Financial Economics 13(1984):187-221.

Nadolnyak, D., X. Shen, and V. Hartarska. "Farm income and output and lending by the farm credit system,." Agricultural Finance Review 77(2017):125-136.

National Climatic Data Center, National Oceanic and Atmospheric Administration (NCDC-NOAA). 2013. Internet site: http://wwwl.ncdc.noaa.gov/pub/data/cirs/ (Accessed March 2013).

O'Donnell, C.J. "Non-parametric estimates of the components of productivity and profitability change in U.S. agriculture." American Journal of Agricultural Economics 94(2012):873-890.

Paul, C.M., R. Nehring, D. Banker, and A. Somwaru. "Scale economies and efficiency in U.S. agriculture: Are traditional farms history?” Journal of Productivity Analysis 22(2004):185-205.

Pedroni, P. "Panel cointegration: Asymptotic and finite sample properties of pooled time series tests with an application to the PPP hypothesis.” Econometric Theory 20(2004):597-625.

Rahaman, M.M. “Access to financing and firm growth.” Journal of Banking and Finance 35(2011):709-723.

Sabasi, D, and C.R. Shumway. "Climate change, health care access, and regional influence on components of U.S. agricultural productivity.” Applied Economics 50(2018):6149-6164.

Sherrick, B.J., Barry, P.J., P.N. Ellinger, and G.D. Schnitkey (2004). "Factors influencing farmers' crop insurance decisions." American Journal of Agricultural Economics 86, 103-114.

Shiller, R.J. "U.S. stock markets 1871-present and CAPE ratio." Downloaded data from Irrational Exuberance [Princeton University Press 2000, Broadway Books 2001, 2nd ed., 2005]. Internet site: http://www.econ.yale.edu/ shiller/data.htm (Accessed March 2016).

Shumway, C.R., B.M. Fraumeni, L.E. Fulginiti, J.D. Samuels, and S.E. Stefanou. "U.S. agricultural productivity: A review of USDA Economic Research Service methods." Applied Economic Perspectives and Policy 38(2016):1-29.

Stiglitz, J.E., and A. Weiss. "Credit rationing in markets with imperfect information." American Economic Review 71(1981):393-410.

Sufi, A.. "Bank lines of credit in corporate finance: An empirical analysis." Review of Financial Studies 22(2009):1057-1088.

U.S. Bureau of Economic Analysis (USBEA). Real gross domestic product, 2017. Internet site: https://fred.stlouisfed.org/ series/GDPC1 (Accessed August 2017).

U.S. Congressional Budget Office (USCBO). Real potential gross domestic product [GDPPOT], 2017. Internet site: https:// fred.stlouisfed.org/series/GDPPOT (Accessed August 2017).

U.S. Department of Agriculture, Economic Research Service (USDA-ERS). Agricultural productivity in the U.S. Table 23. Price indices and implicit quantities of farm outputs and inputs by State, 1960-2004, 2013a. Internet site: http://www.ers. usda.gov/data-products/agricultural-productivity-in-the-us.aspx (Accessed October 2013).

U.S. Department of Agriculture, Economic Research Service (USDA-ERS). Farm income and wealth statistics. Archive of suspended tables: State-level farm sector balance sheets, 1960-2003, 2013b. Internet site: http://www.ers.usda.gov/dataproducts/farm-income-and-wealth-statistics/data-files-us-and-state-level-farm-income-and-wealth-statistics.aspx (Accessed March 2013).

U.S. Department of Agriculture, Economic Research Service (USDA-ERS). Farm income and wealth statistics. Farm income statements, U.S. and States: Returns to operators, 2013c. Internet site: http://www.ers.usda.gov/data-products/ 
farm-income-and-wealth-statistics/data-files-us-and-state-level-farm-income-and-wealth-statistics.aspx (Accessed March 2013).

U.S. Department of Agriculture, Economic Research Service (USDA-ERS). Urban influence codes, 2013d. Internet site: http://www.ers.usda.gov/Data/UrbanInfluenceCodes/ (Accessed October 2013).

U.S. Department of Agriculture, Economic Research Service (USDA-ERS). Price indices and implicit quantities of farm outputs and inputs by state, 1960-2004, 2018. Internet site: https://www.ers.usda.gov/data-products/agriculturalproductivity-in-the-us/ (Accessed February 2018).

U.S. Department of Agriculture, Economic Research Service (USDA-ERS). Farm income and wealth statistics. Farm sector balance sheet and selected financial ratios, 2020. Internet site: https:/www.ers.usda.gov/data-products/farm-income-andwealth-statistics/data-files-us-and-state-level-farm-income-and-wealth-statistics/ (Accessed August 2020).

U.S. Department of Agriculture, Economic Research Service (USDA-ERS). Documentation for the farm sector balance sheets, 2021. Internet site: https://www.ers.usda.gov/data-products/farm-income-and-wealth-statistics/documentationfor-the-farm-sector-balance-sheet/ (Accessed March 2021).

U.S. Department of Labor, Bureau of Labor Statistics (USDL-BLS). Producer price index (PPI) data for farm products, 2018. Internet site: https://data.bls.gov/pdq/SurveyOutputServlet (Accessed February 2018).

Villavicencio, X., B.A. McCarl, X. Wu, and W.E. Huffman. "Climate change influences on agricultural research productivity." Climate Change 119(2013):815-824.

Witte, T., E.A. DeVuyst, B. Whitacre, R. Jones. "Modeling the impact of distance between offices and borrowers on agricultural loan volume." Agricultural Finance Review 75(2015):484-498

Wooldridge, J.M. Econometric Analysis of Cross Section and Panel Data. Cambridge, MA: MIT Press, pp.282-283, 2002.

Cite this article: Sabasi D, Shumway CR, and Kompaniyets L (2021). Analysis of Credit Access, U.S. Agricultural Productivity, and Residual Returns to Resources. Journal of Agricultural and Applied Economics 53, 389-415. https://doi.org/10.1017/ aae.2021.17 